NBER WORKING PAPER SERIES

\title{
MACROECONOMICS OF PERSISTENT SLUMPS
}

\author{
Robert E. Hall \\ Working Paper 22230 \\ http://www.nber.org/papers/w22230 \\ NATIONAL BUREAU OF ECONOMIC RESEARCH \\ 1050 Massachusetts Avenue \\ Cambridge, MA 02138 \\ May 2016
}

Chapter prepared for the Handbook of Macroeconomics, John Taylor and Harald Uhlig, eds. The Hoover Institution supported this research. The research is also part of the National Bureau of Economic Research's Economic Fluctuations and Growth Program. I thank Gauti Eggertsson, Wouter den Haan, and Cosmin Ilut for illuminating conference discussions, and Valerie Ramey and the editors for comments. Complete backup for all of the calculations is available from my website, stanford.edu rehall. The views expressed herein are those of the author and do not necessarily reflect the views of the National Bureau of Economic Research.

NBER working papers are circulated for discussion and comment purposes. They have not been peer-reviewed or been subject to the review by the NBER Board of Directors that accompanies official NBER publications.

(C) 2016 by Robert E. Hall. All rights reserved. Short sections of text, not to exceed two paragraphs, may be quoted without explicit permission provided that full credit, including (C) notice, is given to the source. 
Macroeconomics of Persistent Slumps

Robert E. Hall

NBER Working Paper No. 22230

May 2016

JEL No. E24,E32,J21

\begin{abstract}
$\underline{\text { ABSTRACT }}$
In modern economies, sharp increases in unemployment from major adverse shocks result in long periods of abnormal unemployment and low output. This chapter investigates the processes that account for these persistent slumps. The data are from the economy of the United States, and the discussion emphasizes the financial crisis of 2008 and the ensuing slump. The framework starts by discerning driving forces set in motion by the initial shock. These are higher discounts applied by decision makers (possibly related to a loss of confidence), withdrawal of potential workers from the labor market, diminished productivity growth, higher markups in product markets, and spending declines resulting from tighter lending standards at financial institutions. The next step is to study how driving forces influence general equilibrium, both at the time of the initial shock and later as its effects persist. Some of the effects propagate the effects of the shock---they contribute to poor performance even after the driving force itself has subsided. Depletion of the capital stock is the most important of these propagation mechanisms. I use a medium-frequency dynamic equilibrium model to gain some notions of the magnitudes of responses and propagation.
\end{abstract}

Robert E. Hall

Hoover Institution

Stanford University

Stanford, CA 94305-6010

and NBER

rehall@gmail.com 


\begin{tabular}{cccccc}
\hline \hline & & \multicolumn{3}{c}{$\begin{array}{r}\text { Ratio of later unemployment rate to peak } \\
\text { rate, by number of years later }\end{array}$} \\
\cline { 3 - 6 } Peak year & Peak rate & \multicolumn{3}{c}{3} & 4 \\
\hline 1975 & 8.5 & 0.91 & 0.84 & 0.72 & 0.69 \\
1982 & 9.7 & 0.99 & 0.77 & 0.74 & 0.72 \\
1992 & 7.5 & 0.92 & 0.81 & 0.75 & 0.72 \\
2010 & 9.6 & 0.93 & 0.84 & 0.77 & 0.65 \\
\hline \hline
\end{tabular}

Table 1: Unemployment in the Four Serious Slumps since 1948

Beginning in 2008, output and employment in the United States dropped well below its previous growth path. Eight years later, unemployment is back to normal but output remains below the growth path. Japan has been in a persistent slump for two decades. And many of the advanced economies of Europe are in slumps, several quite deep. This chapter reviews the macroeconomics of slumps taking the American experience as a leading example.

The adverse shock that launches a slump generally triggers a rapid contraction of output and employment, with a substantial jump in unemployment. This phase - the recession - is usually brief. It ended in mid-2009 in the recent case. The recovery from the trough often lasts many years. The slump is the entire period of substandard output and employment and excess unemployment. In the recent U.S. case, the slump lasted from late 2008 until around the end of 2014. Dating the end of a slump is challenging, because some of the state variables accounting for depressed output, notably the capital stock, take many years to return to normal. Output in 2014 was well below its earlier trend path.

Persistent slumps did not begin with the one that originated from the financial crisis of 2008. The Great Depression remains much the deepest and longest slump in the American record since the beginning of national income accounting. Table 1 shows that the persistence of unemployment was about equally high in the four major slumps that occurred after the introduction of the household unemployment survey in 1948. Normal unemployment in the U.S, measured as its average over the period starting in 1948, is 6.0 percent. In all four slumps, unemployment remained above normal three years following the peak of unemployment, and in only one slump, the milder one associated with the recession of 199091, did unemployment drop below normal four years after the peak of unemployment. 
Other accounts of persistent shortfalls in output and employment, focusing on the financial crisis and its aftermath, include Kocherlakota (2013), Christiano, Eichenbaum and Trabandt (2016), Christiano, Trabandt and Walentin (2010), Benigno and Fornaro (2015), Petrosky-Nadeau and Wasmer (forthcoming, 2015), Gertler, Sala and Trigari (2008), Mian and Sufi (2010), Reifschneider, Wascher and Wilcox (2013), Hall (2013), and Hall (2014).

\section{The Slump Following the 2008 Financial Crisis}

This section provides the factual foundation for the chapter by describing events in the U.S. economy around the time of the 2008 crisis, through to 2014 . I provide plots of key macroeconomic variables with brief discussions. The rest of the chapter considers the ideas and models that seem most relevant to understanding those events.

Figure 11 shows that real GDP fell dramatically right after the crisis and remained below its prior growth path even six years after the crisis. Plainly the crisis had a persistent effect on the total output of goods and services. Figure 2 shows that real consumption expenditures behaved similarly to real GDP, with no sign of regaining its earlier growth path over the period following the 2008 crisis. Figure 3 shows persistent shortfalls from the growth path of employment. Figure 4 shows that unemployment rose to a high level and returned to its longrun average of 5.8 percent at the end of 2014, six years after the crisis. The unemployment rate is the only major macroeconomic indicator that returned to normal within the six-year period considered here. Figure 5 shows that the labor force shrank after the crisis, relative to the working-age population, and that no recovery of the labor force occurred during the recovery. Figure 6 shows that average real compensation per household, which had grown briskly through 2000, flattened before the crisis, fell sharply just after the crisis, and only regained its previous level in 2014. Figure 7 shows that the business capital stock - in the sense of an index of capital services available to private businesses - grew much less rapidly than normal immediately after the crisis. Its growth rate returned closer to normal, but left a considerable shortfall in capital relative to trend, as of 2014. Figure 8 shows that private business total factor productivity grew rapidly from 1989 through 2006. A dip in productivity began in 2007. Though productivity grew at normal rates during the recovery, it did not make up for the cumulative decline just after the crisis. Figure 9 shows the index of the share of the total income generated in the U.S. economy that accrues to workers, including fringe benefits. It tends to have a high level in recession years, to fall during the 


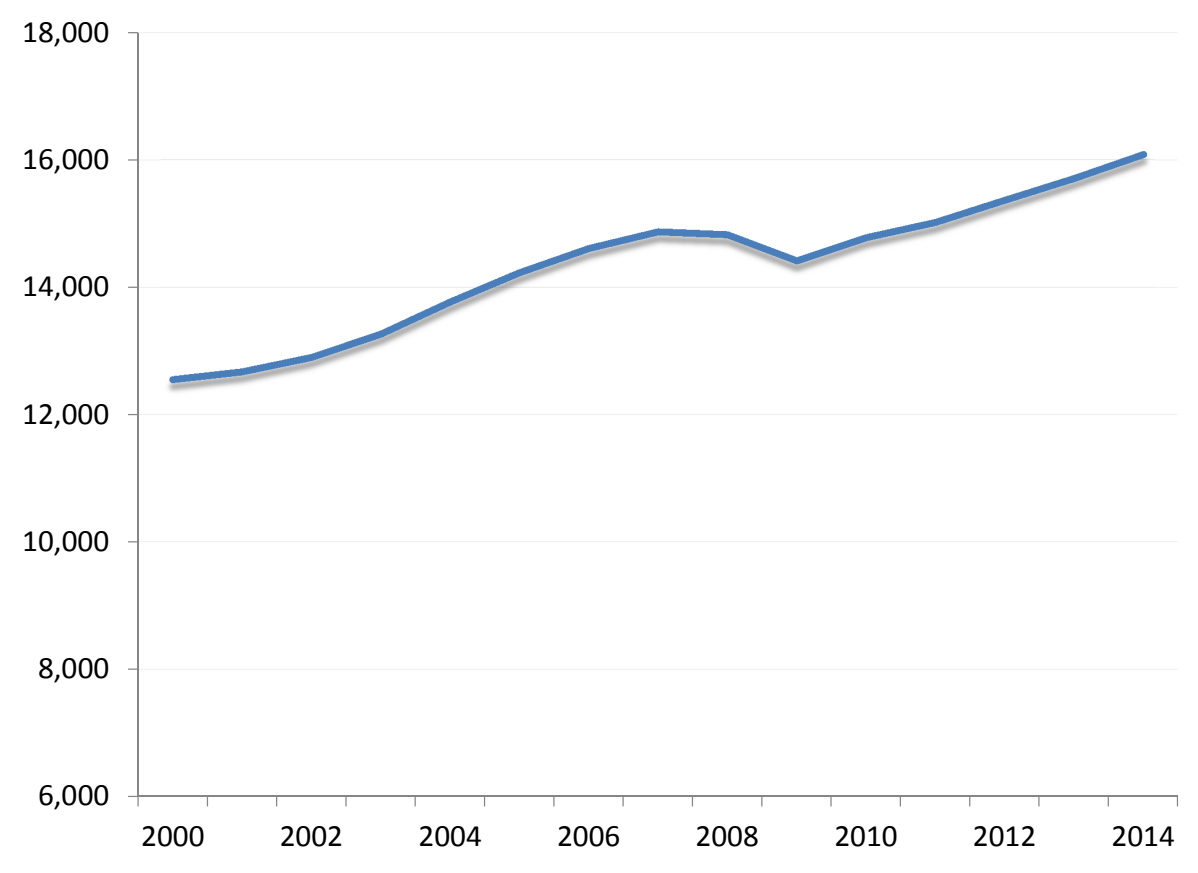

Figure 1: Real GDP, 2000-2014, Billions of 2009 Dollars

first half of the ensuing expansion, then rise back to a high level at the next recession. But superimposed on that pattern is a general decline that cumulates to about 10 percent over the period. Like the general declining trend in earnings, the decline in the share seems to have started around 2000.

\section{Driving Forces}

I use the term driving force to mean either an exogenous variable or an endogenous variable that is taken as an input to a macro model. An example of the latter case is a rise in the discount rate for investment and job creation, triggered by a financial crisis. There is no claim that the discount increase is exogenous. Rather, the hypothesis is that a process outside the model - say a collapse of house prices - influences the model through a higher discount rate. The same process outside the model may enter the model through more than one driving force. For example, the collapse of housing prices may also affect consumption demand by lowering borrowing opportunities of constrained households.

Here I provide an informal review of the driving forces that macroeconomics has identified to account for persistent slumps. 


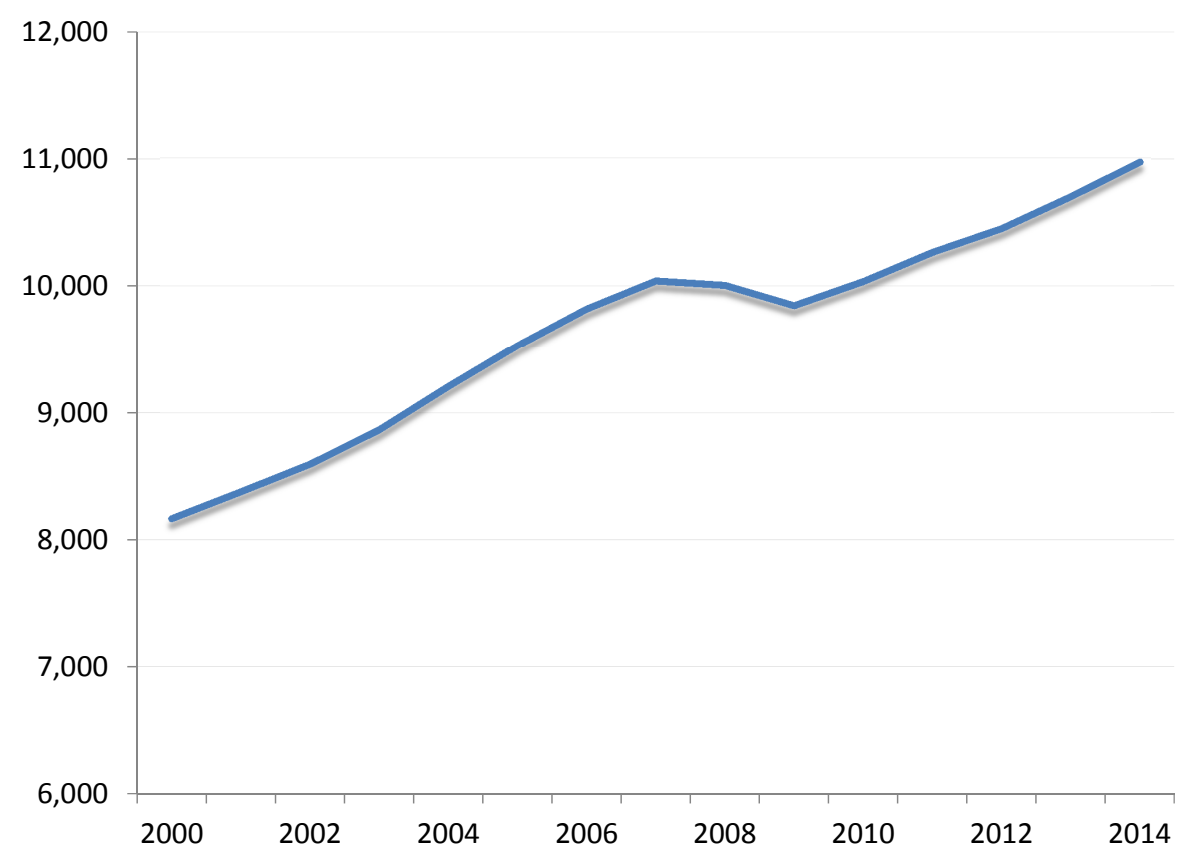

Figure 2: Real Consumption Expenditure, 2000-2014, Billions of 2009 Dollars

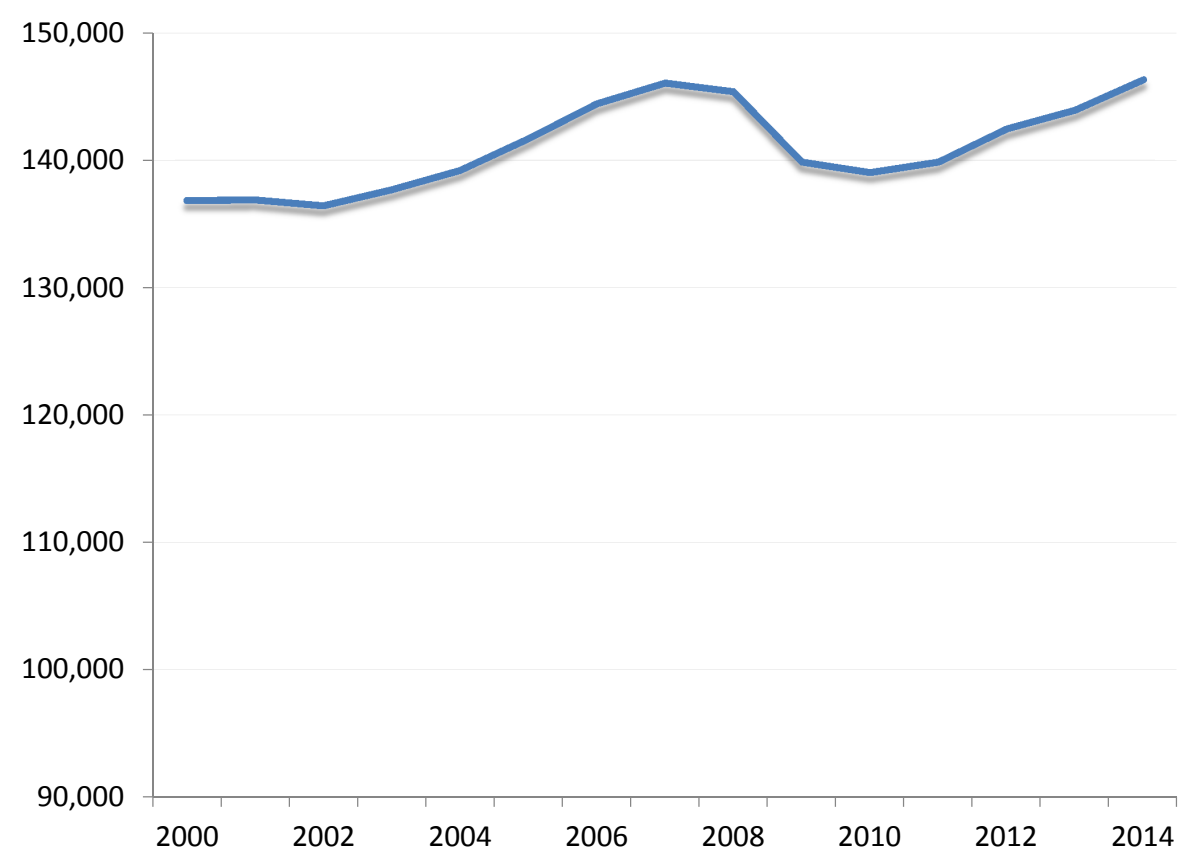

Figure 3: Employment, 2000-2014, Thousands of Workers 


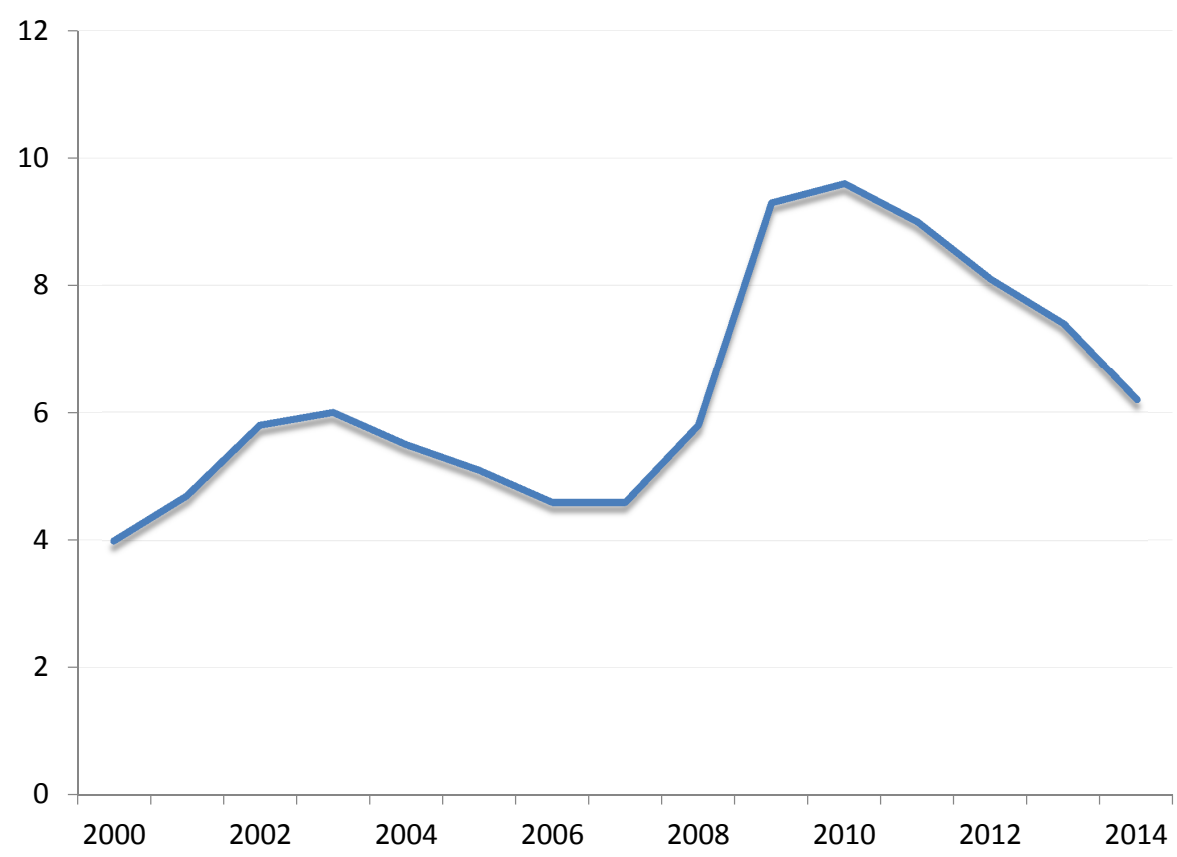

Figure 4: Unemployment, 2000-2014, Percent of Labor Force

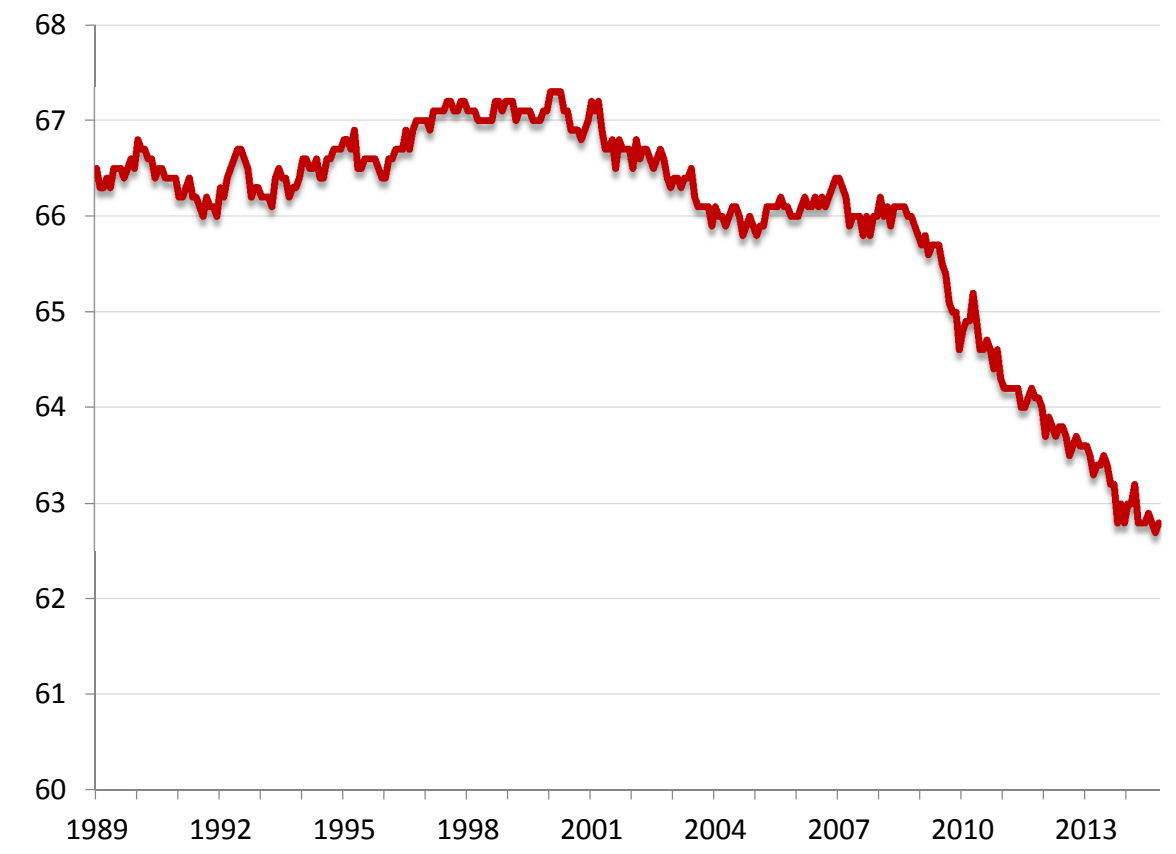

Figure 5: Percent of Working-Age Population in the Labor Force, 2000-2014 


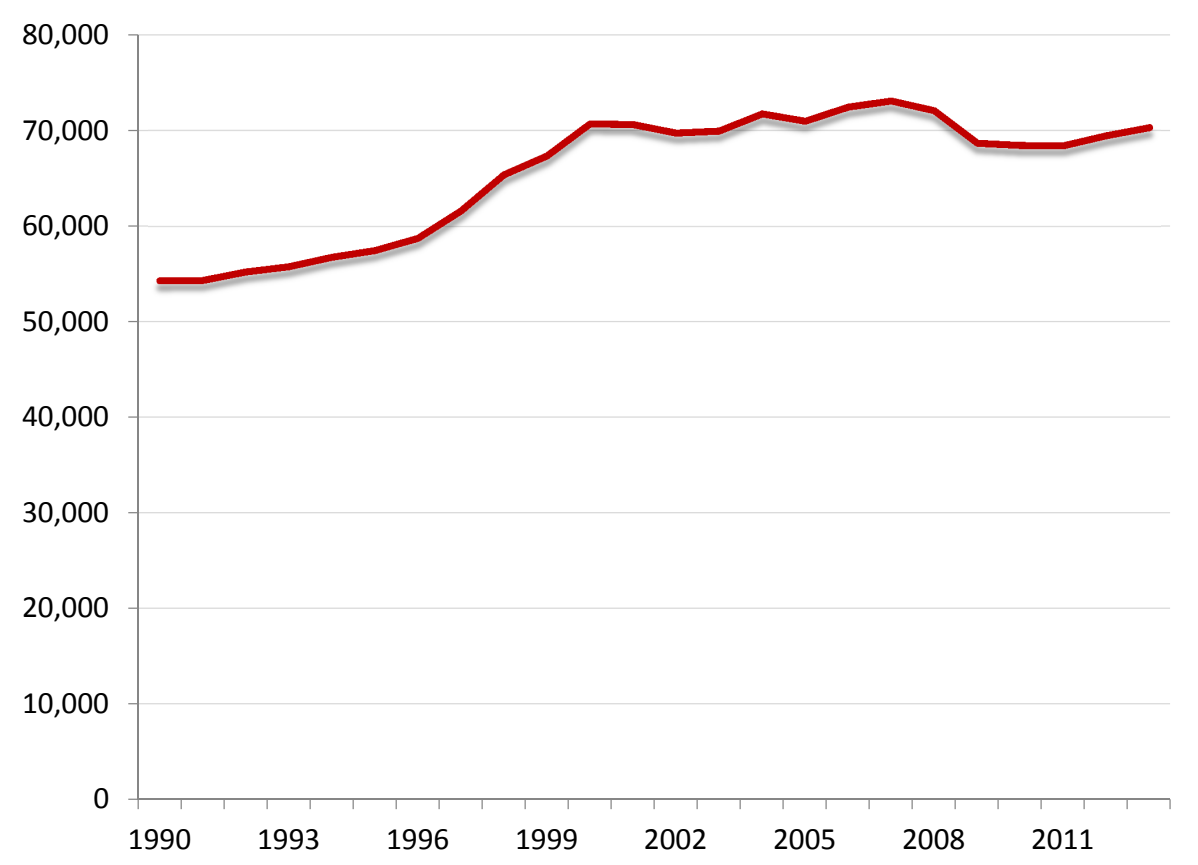

Figure 6: Average Real Earnings per Household, 2009 Dollars, 1990-2014

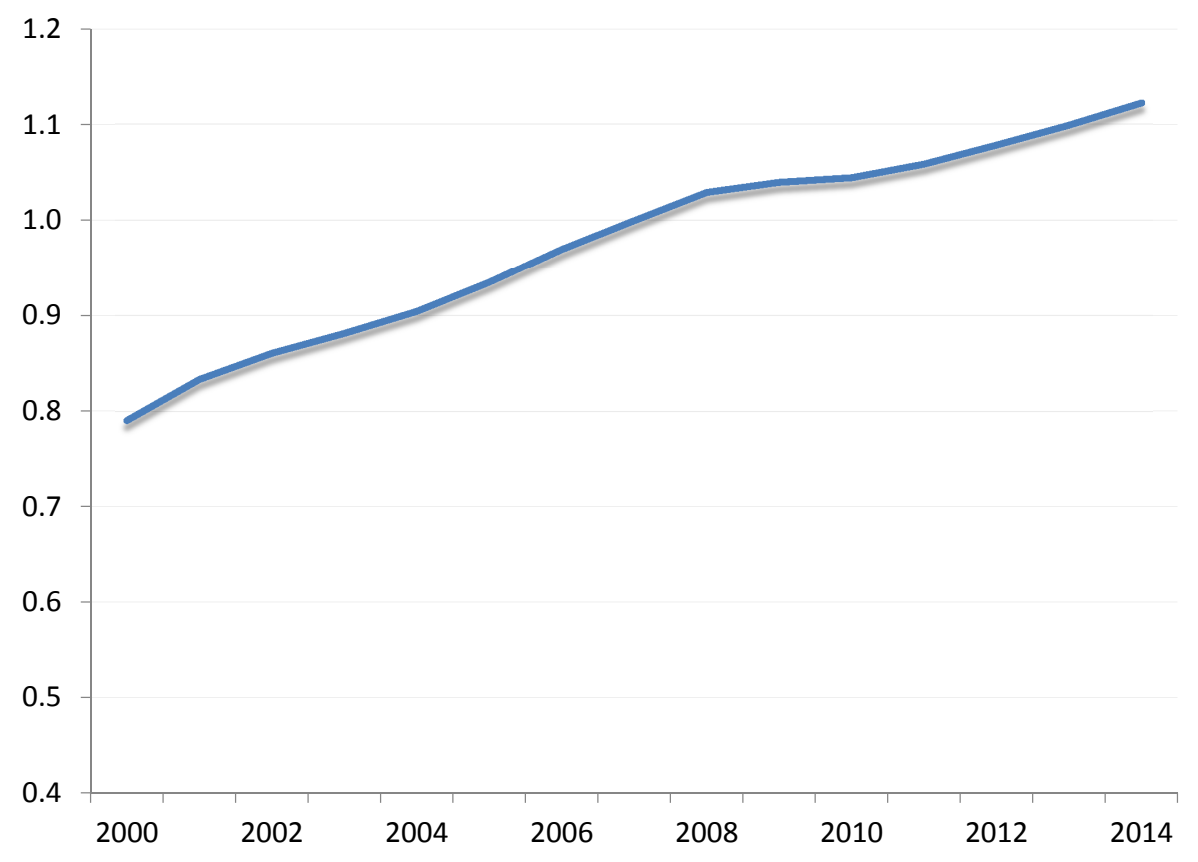

Figure 7: Index of Capital Services, $2007=1,2000-2014$ 


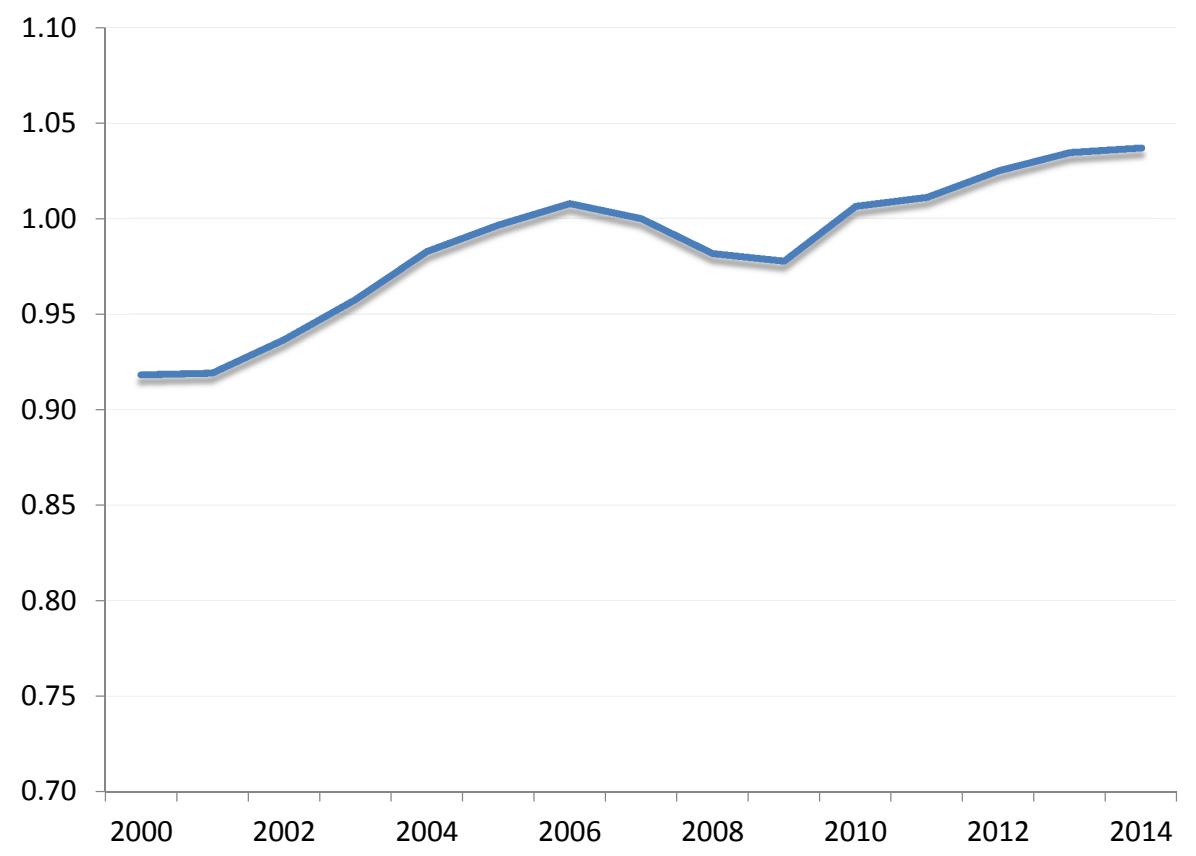

Figure 8: Index of Total Factor Productivity, $2007=1$, 2000-2014

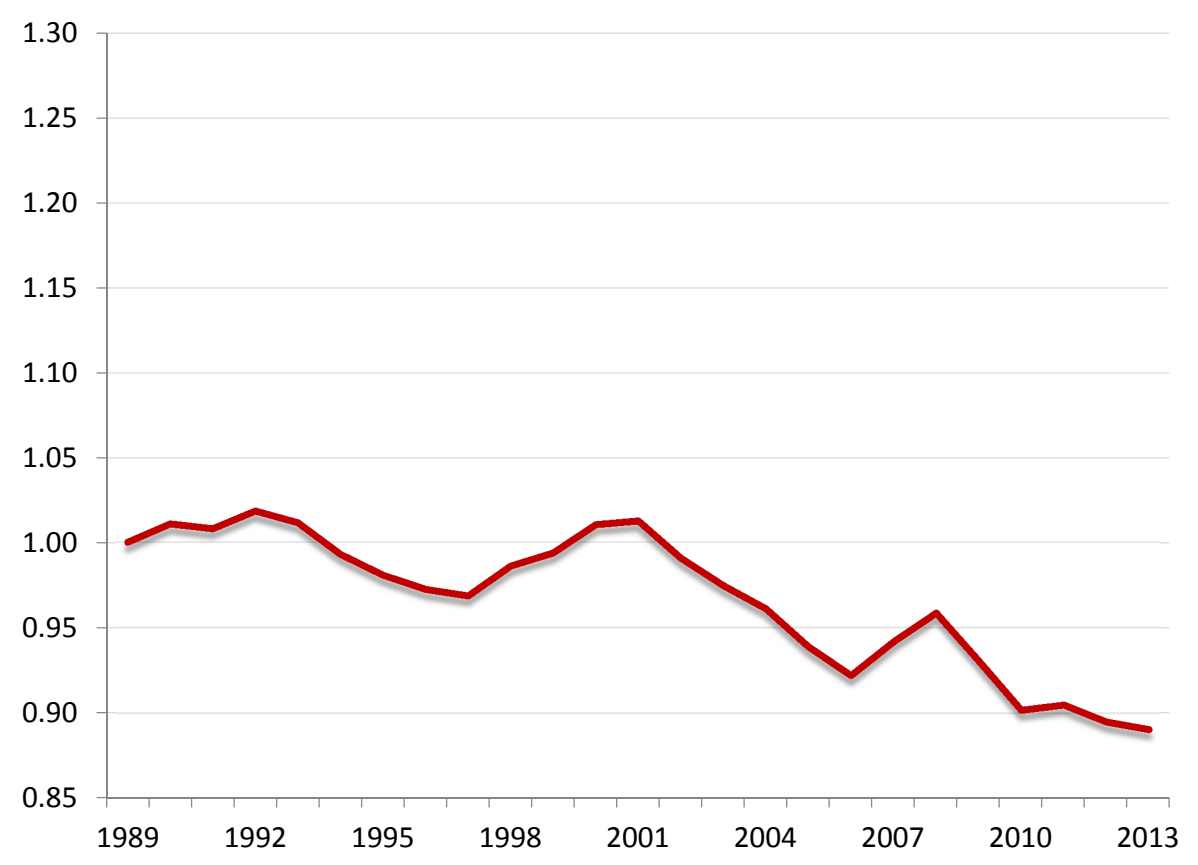

Figure 9: Labor share 


\subsection{Labor-force participation}

A discovery in recent U.S. experience has been the importance of a major decline in laborforce participation. In past slumps, participation remained close to unchanged - the economy has not had a consistent tendency for the labor force to shrink when job-finding became more difficult. As of 2015, the U.S. labor market had returned to normal tightness, as measured by job-finding and job-filling rates, yet a large decline in participation starting around 2000 has not reversed. The decline in participation is an important contributor to the divergent behavior of output and employment, on the one hand, and labor-market tightness, on the other hand. Judged by the latter, the slump triggered by the financial crisis of 2008 is over, yet output and employment are far below the paths expected just prior to the crisis.

Movements in participation not directly tied to labor-market tightness need to be added to the list of phenomena associated with episodic slumps. Even if a major shock did not cause a subsequent decline in participation, if a decline happens to occur during a slump, the shortfall in employment and output will be negatively affected.

Elsby, Hobijn and Şahin (2013) is a recent investigation of the decline in participation. Autor (2011) describes the disability benefits that may be a contributor to that decline.

\subsection{The capital wedge}

A key fact in understanding the slump following the financial crisis is the stability of business earnings. Figure 10 shows the earnings of private business (the operating surplus from the NIPAs, revenue less non-capital costs) as a ratio to the value of capital (plant, equipment, software, and other intangibles, from the Fixed Assets account of the NIPAs). Earnings fell in 2007 from their normal level of just over 20 percent, but recovered most of the way by 2010, when output and employment remained at seriously depressed levels.

A basic question is why investment fell so much despite the continuing profitability of business activities. Macroeconomics has gravitated toward an analysis of wedges as ways of describing what seem to be failures of incentives. The capital wedge is the difference between the measured return to investment and the financial cost of investment. I take the latter to be the risk-free real interest rate. The risk premium is one component of the wedge between the return to business capital and the risk-free interest rate. Other components are taxes, financial frictions, and liquidity premiums. To measure the total wedge, I calculate the annual return to capital and subtract the one-year safe interest rate from it. Later, I 


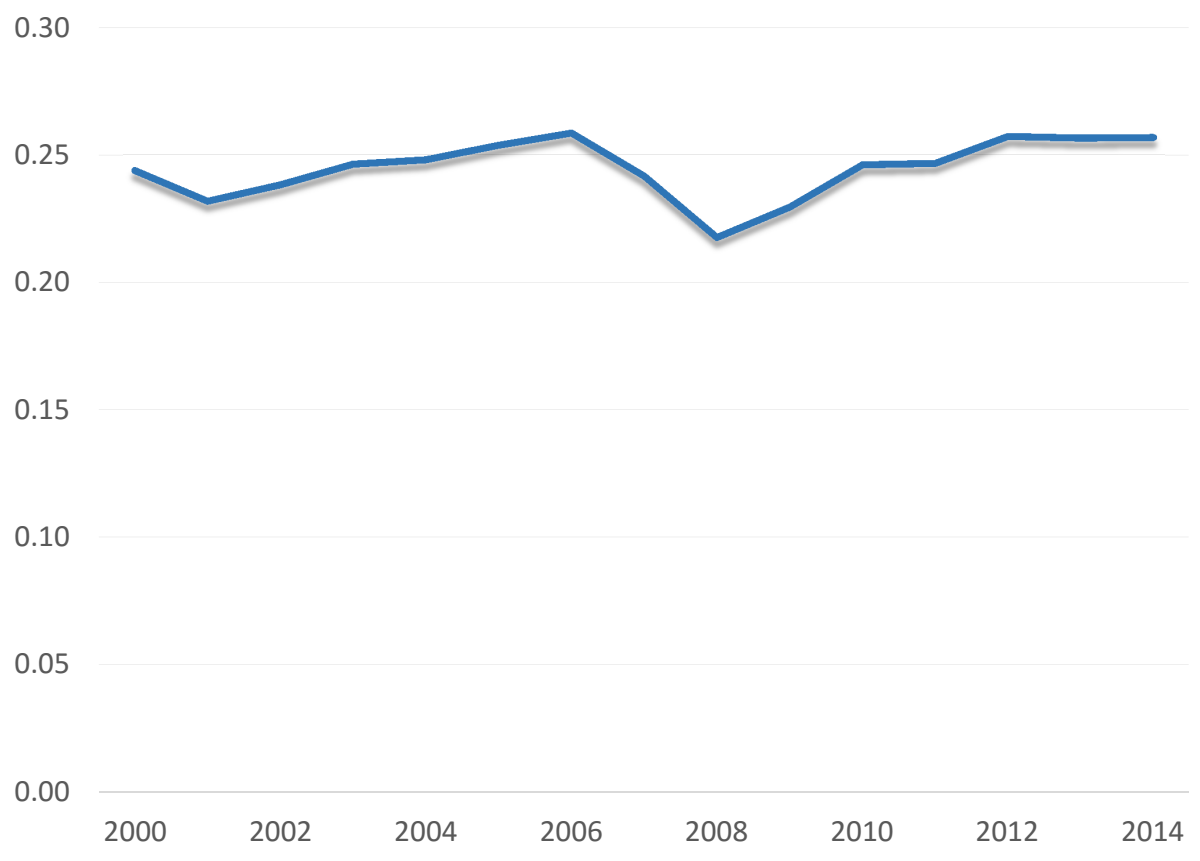

Figure 10: Business Earnings as a Ratio to the Value of Capital

decompose the total wedge into one component, interpreted as an extra discount on risky capital earnings not explained by finance theory, and a second, interpreted as an extra premium on safe returns not explained by finance theory.

The calculation of the return to capital uses the following thought experiment: A firm purchases one extra unit of investment. It incurs a marginal adjustment cost to install the investment as capital. During the year, the firm earns incremental gross profit from the extra unit. At the end of the year, the firm owns the depreciated remainder of the one extra unit of installed capital. Installed capital has a shadow value measured by Tobin's $q$.

Installation incurs a marginal cost at the beginning of the period of $\kappa\left(k_{t} / k_{t-1}-1\right)$. Thus the shadow value of a unit of installed capital at the beginning of the year is

$$
q_{t}=\kappa\left(\frac{k_{t}}{k_{t-1}}-1\right)+1
$$

units of capital. From its investment of a unit of capital at the beginning of year $t$ together with the marginal installation cost - with a total cost of $q_{t} p_{k, t}$ - the firm's nominal return ratio is the gross profit per unit of capital $\pi_{t} / k_{t}$ plus the depreciated value of the capital in year $t+1$, all divided by its original investment:

$$
1+r_{k, t}=\frac{1}{q_{t} p_{k, t}}\left[\frac{\pi_{t}}{k_{t}}+\left(1-\delta_{t}\right) q_{t+1} p_{k, t+1}\right] .
$$


Gross profit includes pre-tax accounting profit, interest payments, and accounting depreciation. In principle, some of proprietors' income is also a return to capital - non-corporate business owns significant amounts of capital — but attempts to impute capital income to the sector result in an obvious shortfall in labor compensation measured as a residual. The reported revenue of the non-corporate business sector is insufficient to justify its observed use of human and other capital. Note that business capital as measured in the NIPAs now includes a wide variety of intangible components in addition to plant and equipment.

The implied wedge between the return to capital and the risk-free real interest rate $r_{f, t}$ is the difference between the nominal rate of return to capital and the one-year safe nominal interest rate:

$$
r_{k, t}-r_{f, t}
$$

This calculation is on the same conceptual footing as the investment wedge in Chari, Kehoe and McGrattan (2007), stated as an interest spread. Note that the wedge is in real units - the rate of inflation drops out in the subtraction.

Figure 11 shows the values of the business capital wedge for two values of the adjustment cost parameter $\kappa$, calculated from equation (3), combining plant, equipment, and intellectual property. On the left, $\kappa$ is taken as zero and on the right, as 2 . The former value accords with the evidence in Hall (2004) and the latter with the consensus of other research on capital adjustment costs. The value $\kappa=2$ corresponds to a quarterly parameter of 8 .

The two versions agree about the qualitative movements of the wedge since 1990, but differ substantially in volatility. The wedge was roughly steady or falling somewhat during the slow recovery from the recession of 1990, rose to a high level in the recession of 2001, declined in the recovery, and then rose to its highest level after the crisis. The two calculations agree that the wedge remained at a high level of about 18 percent per year through 2013.

Hall (2011a) discusses the surprising power of the financial wedge over general economic activity. The adverse effect of the wedge on capital formation cuts market activity in much the same way as taxes on consumption or work effort.

One branch of the recent literature on the propagation of financial collapse into a corresponding collapse of output and employment emphasizes agency frictions in businesses and financial intermediaries. The simplest model in the case of an intermediary-completely dominant in this literature though not obviously descriptive of the actual U.S. economygrants the intermediary the opportunity to abscond with the investors' assets. Absconding 


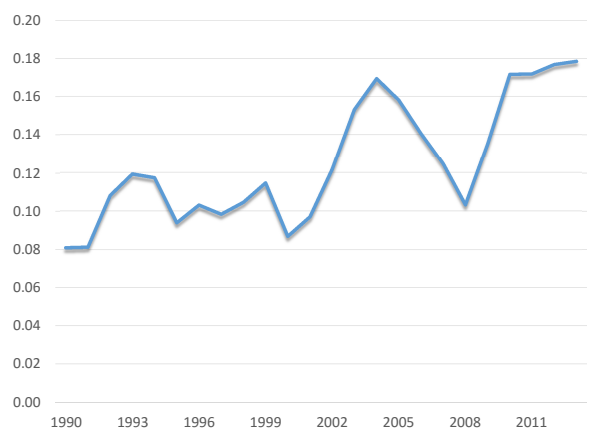

(a) $\kappa=0$

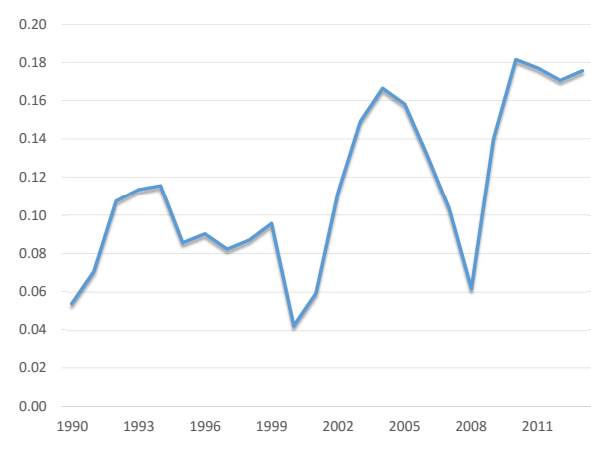

(b) $\kappa=2$

Figure 11: The Capital Wedge for Two Values of the Adjustment Cost $\kappa$

takes place if the intermediary's continuation value falls short of the value of absconding, taken to be some fraction of the amount stolen from the investors. If the intermediary's equity falls on account of a crisis - for example, if mortgage-backed securities suffer a large capital loss - the investors need to restore the intermediary's incentive to perform by granting a larger spread between the lending rate the intermediary earns and the funding rate it pays to the investors. Hence spreads rise after a financial crisis. This view is consistent with the actual behavior of the spread between the return to capital and the risk-free rate.

The same type of agency friction can occur between a non-financial business and its outside investors. Depletion of the equity in the business will threaten the investors' capital. They need to raise the rents earned by the business to increase the continuation values of the insiders, and again spreads will rise.

Gertler and Kiyotaki (2011) cover this topic thoroughly in a recent volume of the Handbook of Monetary Economics. Brunnermeier, Eisenbach and Sannikov (2012) is another recent survey. Key contributions to the literature include Bernanke, Gertler and Gilchrist (1999), Kiyotaki and Moore (2012), Gertler and Karadi (2011), Brunnermeier and Sannikov (2014), and Gertler and Kiyotaki (2011). See also Krishnamurthy and Vissing-Jorgensen (2013), He and Krishnamurthy (2015), Adrian, Colla and Shin (2012), and Korinek and Simsek (2014). 


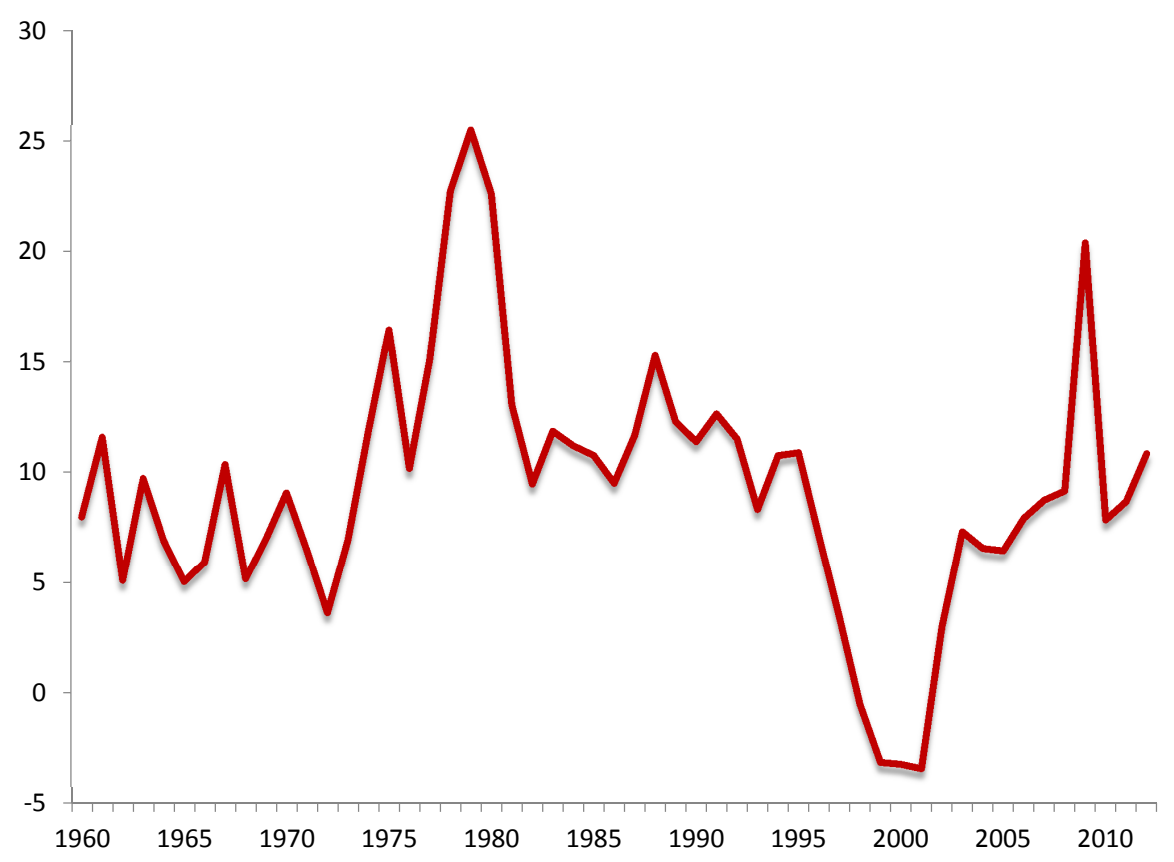

Figure 12: The S\&P Risk Premium, 1960 through 2012

\subsection{Discounts and confidence}

A second branch of the literature linking financial collapse to rising spreads considers widening risk premiums in crises and ensuing slumps. Cochrane (2011) discusses the high volatility of the risk premium in the stock market, measured as the discount rate less the risk-free rate. Lustig and Verdelhan (2012) document the tendency for discounts to rise in slumps.

A basic property of the stock market is that, when the level of the stock market is low, relative to a benchmark such as dividends, discounts are higher-see Campbell and Shiller (1988). Normalized consumption is another reliable predictor of returns. Figure 12 shows the equity premium for the $\mathrm{S} \& \mathrm{P}$ stock-price index from a regression of annual returns on those two variables (see Hall (2015) for further discussion and details of its construction). The risk premium spiked in 2009. Notice that it is not nearly as persistent as the slump itself - the premium was back to normal well before unemployment fell back to normal and long before investment recovered.

Macroeconomics and finance are currently debating the explanation for the high volatility of discounts. In principle, high discounts arise when the marginal utility of future consumption is high. Generating this outcome in a model is a challenge. Marginal utility would need to be highly sensitive to consumption to generate observed large movements in discounts 


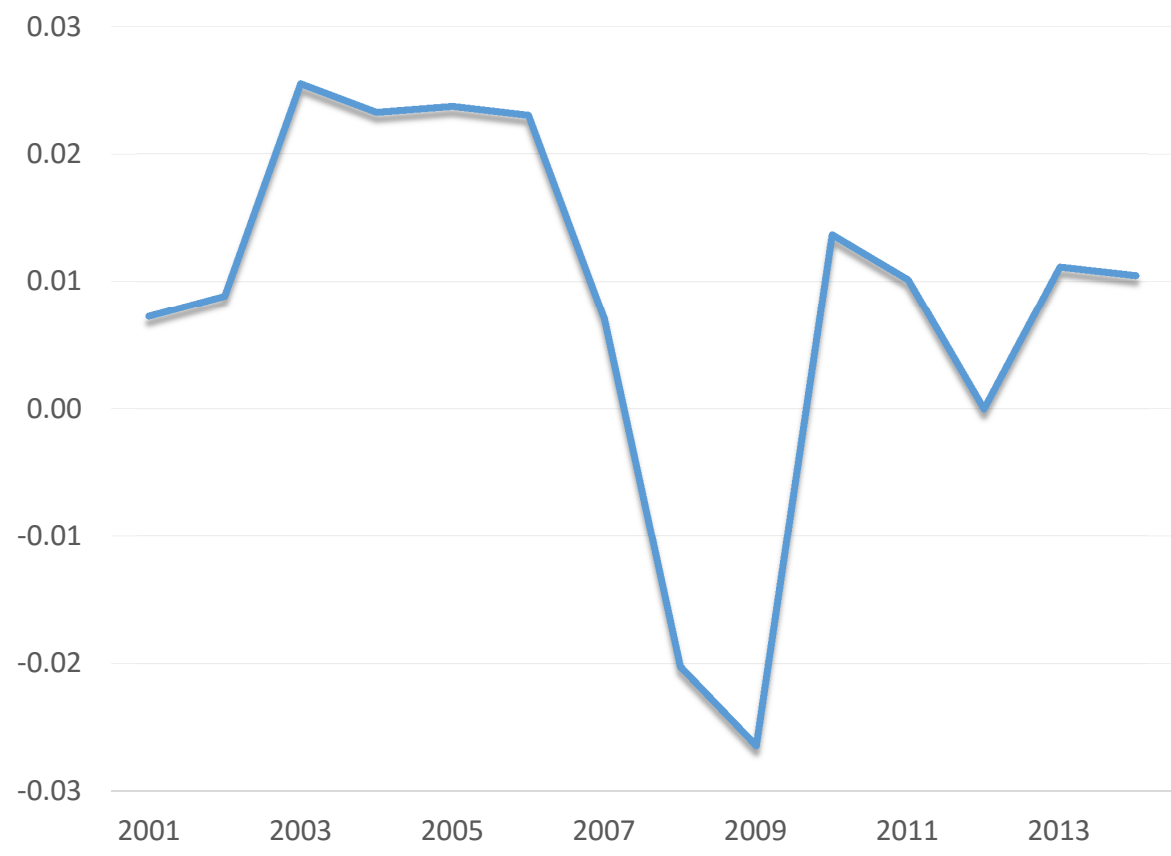

Figure 13: Growth Rate of Real Consumption of Nondurable Goods per Person

from the modest expected declines in consumption that occur even in severe contractions. Contractions in consumption appear to be almost completely surprises. If a model implied that occasional drops in consumption occurred as surprises, and consumption then grew faster than normal to regain its previous growth path, the discount rate would fall after a crisis, because marginal utility would be lower in the future.

Figure 13 shows the history of the growth of real consumption of nondurable goods per person from 2001 through 2014. The largest decline was in 2009, at 2.5 percent, about 3.5 percent below its normal growth. With a coefficient of marginal utility with respect to consumption of 2 (elasticity of intertemporal substitution of 0.5 ), the effect on marginal utility would be a substantial 7 percent. But this applies to a fully foreseen decline. The process for consumption change is close to white noise, so the hypothesis of a large negative expected change seems untenable.

Bianchi, Ilut and Schneider (2012) propose a mechanism to overcome the problem that expected increases in marginal utility are inconsistent with the observed behavior of consumption. They disconnect discounts from rational expectations of changes in marginal utility by invoking ambiguity aversion. Investors form discounts based on their perceptions of a bad-case realization of marginal utility. During periods when investors have unusually pessimistic views, discounts are high. 
Angeletos, Collard and Dellas (2014) overcome the problem in a related way. Investors form expectations about the future state of the economy based on biased beliefs about beliefs of other decision makers. When these second-order beliefs are unusually pessimistic, investors believe that their own future consumption will be lower and their future marginal utility higher, and thus apply higher discounts. The authors use the term confidence to refer to optimism in second-order beliefs.

In general, if a financial crisis or other salient event causes investors to shift their beliefs toward higher future marginal utility, discounts will rise. To the extent that the mean of future marginal utility rises, the safe real rate will increase along with the discounts applied to risky returns. To harness the mechanism to explain the decline in the safe rate in the Great Slump along with the rise in the risky discount, the change in the distribution of future marginal utility needs to lower the mean but raise the expected product of marginal utility and the payoffs that govern the levels of employment and output.

The spreads between yields on risky and safe bonds of the same maturity are informative about variations in discounts. Philippon (2009) argues that the bond spread may be more informative. Because the difference in the values of a risky bond and a safe bond is sensitive only to shocks that alter payoffs conditional on default, and default is relatively rare for bonds, the bond spread encodes information about the rare, serious events that could account for high discounts on business income and low discounts on safe payoffs. Figure 14 shows the option-adjusted spread between BBB-rated bonds and Treasurys of the same maturity.

The spread widened dramatically in 2009, supporting the hypothesis that the perceived probability of a collapse of business cash flow had increased substantially. But the widening was transitory. The spread returned to historically normal levels in 2010 and remained there subsequently. It would take a powerful propagation mechanism for the change in perceptions to account for the persistent slump after 2010.

Gilchrist, Sim and Zakrajek (2014a), Figures 2 and 3, show IRFs for a spread shock, derived from a vector autoregression. These show relatively little persistence in the shock, but substantial persistence in investment and GDP responses. See also Cúrdia and Woodford (2015).

Other contributions relating to discounts and confidence include Kozlowski, Veldkamp and Venkateswaran (2015), Farmer (2012), He and Krishnamurthy (2013), Gourio (2012), Bianchi et al. (2012), Lustig, Van Nieuwerburgh and Verdelhan (2013), and Eckstein, Setty 


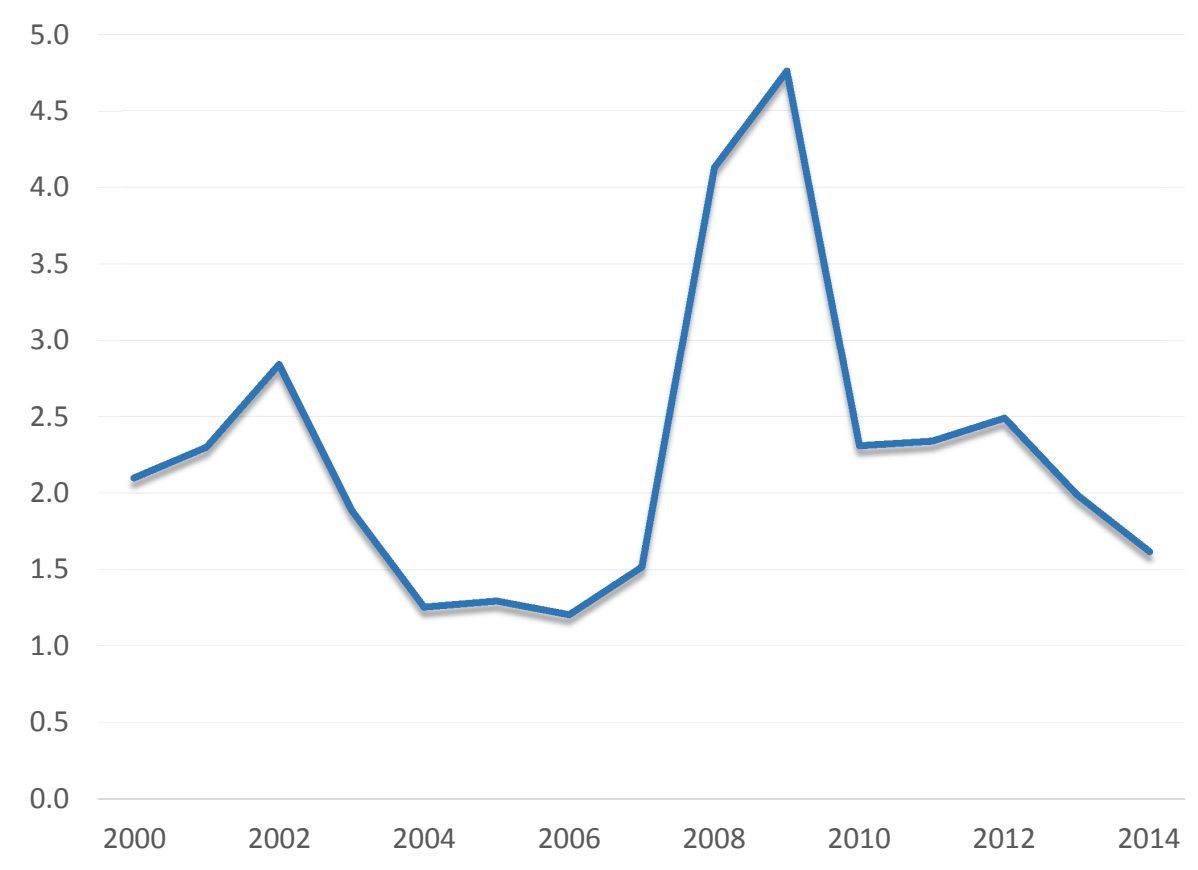

Figure 14: BBB-Treasury Bond Spread

and Weiss (2015). A related topic is the role of fluctuations in uncertainty as a driving force - see Ludvigson, Ma and $\mathrm{Ng}$ (2015) for cites and discussion.

\subsection{Productivity}

A decline in TFP growth was an important factor in the shortfall of output during the post-crisis U.S. slump. Fernald (2014) makes the case that the productivity slowdown was unrelated to the crisis. Rather, he argues, it was a slowdown only relative to rapid TFP growth in the late 1990s and early 2000s, associated with adoption of modern information technology. The episode illustrates the importance of TFP growth as a driving force of medium-term fluctuations, even though TFP is not a consistent driver of sharp contractions.

\subsection{Product-market wedge}

Market power in product markets creates a wedge that has been discussed extensively as a driving force of fluctuations, mainly in the context of the New Keynesian model. Rotemberg and Woodford (1999) discuss how sticky product prices result in cyclical fluctuations in markups - in a slump, prices fall less than costs, so market power rises. In almost any modern macro model, the market-power wedge has a negative effect on employment and output. Nekarda and Ramey (2013) question the evidence supporting this view, with respect 
to shocks apart from productivity. Bils, Klenow and Malin (2014) defend the view, using new evidence.

Gilchrist, Schoenle, Sim and Zakrašek (2014b) show that firms facing higher financial stress after the crisis raised prices (and thus the wedge) relative to other firms, a finding that supports the idea that the product-market wedge rose in general when overall financial stress worsened. The likely mechanism is different from the one in Rotemberg and Woodford (1999) - it is an idea launched in Phelps and Winter (1970). Financially constrained firms borrow, in effect, by raising prices relative to cost and shedding some of their customer bases.

Chari et al. (2007) provide a comprehensive discussion of wedges in general. See also Gourio and Rudanko (2014)

\subsection{Household Deleveraging}

Survey data also show a belief that lending standards to households tightened, for mortgages, loans against home equity, and unsecured borrowing (mostly credit cards). Mian and Sufi (2010) use detailed geographic data to argue that household credit restrictions caused declines in consumption. Mian and Sufi (2012), Mian, Rao and Sufi (2013), and Dynan (2012) document the relation between economic activity and household debt. Bhutta (2012) uses household data to show that families did not repay debt more quickly than usual during the slump. Rather, they took on less debt as it became more difficult to qualify for loans, thanks to rising lending standards and declining equity for existing homeowners who prior to 2008 were using cash-out refinancing and home-equity loans. See also Blundell, Pistaferri and Preston (2008), Petev, Pistaferri and Eksten (2012), and De Nardi, French and Benson (2011).

\section{Propagation Mechanisms}

\subsection{Capital}

The capital stock is an important source of propagation in slumps, a point that has escaped analysis in the cycle-around-trend view of fluctuations. Investment falls sharply in slumps, leaving a depleted capital stock in a slump that lasts several years. Capital depletion also helps account for the divergent behavior of output and labor-market tightness. See Gilchrist et al. (2014a) and Gomme, Ravikumar and Rupert (2011). 


\subsection{Unemployment dynamics}

In the standard search-and-matching model, calibrated as in Shimer (2005), the unemployment rate is a fast-moving state variable. With job-finding rates around 50 percent per month even during slumps, unemployment converges to the stationary level dictated by tightness and the job-finding rate within a few months. Unemployment dynamics have essentially nothing to do with the persistence of slumps.

Some facts about the U.S. labor market call this view into question. Hall (1995) observed that research on the experiences of workers who lost jobs after gaining substantial tenure gave a quite different view of unemployment. Davis and von Wachter (2011) summarize more recent results with the same conclusion and emphasize the discord between the quick recovery from job loss implicit in the basic search-and-matching model and the actual experience of workers with three or more years of tenure following job loss. That experience involves an extended period of low employment - much greater loss than a 50-percent per month re-employment rate - and years of loss of hourly earnings. Jarosch (2014) confirms this view. The aggregate implications are that a wave of layoffs from a major shock, such as the financial crisis, results in an extended period of unemployment and a much longer period of lower productivity of the higher-tenure workers who lose jobs from the shock. Ravn and Sterk (2012) develop a model with two kinds of unemployment to capture this type of heterogeneity among the unemployed.

Some progress has been made in reconciling high monthly job-finding rates with the low recovery from high unemployment following a shock. Hyatt and Spletzer (2013) show that short jobs are remarkably frequent - the distribution of job durations is utterly unlike the exponential distribution with a constant separation hazard usually assumed in search-andmatching models. This finding explains the high job-finding rates found in the CPS - there is a huge amount of churn in the U.S. labor market. Hall and Schulhofer-Wohl (2015) show that job-finding rates over year-long periods are well below what would be expected from monthly job-finding rates. The obvious explanation of this finding is that job-seekers often take interim jobs during much longer spells of mixed unemployment and brief employment.

Shimer (2008) discusses the labor-market wedge as a convenient summary of the effects of labor-market frictions.

Other contributions relating to propagation through unemployment dynamics include Valletta and Kuang (2010b), Cole and Rogerson (1999), Chodorow-Reich and Karabarbounis 
(2016), Davis and von Wachter (2011), Davis, Faberman and Haltiwanger (2012), PetroskyNadeau and Wasmer (2013), Fujita and Moscarini (2013), Jarosch (2014), Rothstein (2011), Petrosky-Nadeau and Zhang (2013), Daly, Hobijn, Şahin and Valletta (2012), Mortensen (2011), Valletta and Kuang (2010a), Sahin, Song, Topa and Violante (2012), Daly, Hobijn and Valletta (2011b), Kuehn, Petrosky-Nadeau and Zhang (2013), Mulligan (2012a), Barnichon and Figura (2012), Estevão and Tsounta (2011), Krueger, Cramer and Cho (2014), Herz and van Rens (2011), Sahin et al. (2012), Farber and Valletta (2013), Kaplan and Menzio (2016), Elsby, Hobijn, Şahin and Valletta (2011), Krueger and Mueller (2011), Davis and Haltiwanger (2014), Hall (2012), Fujita (2011), Hagedorn, Karahan, Manovskii and Mitman (2013), Daly, Hobijn, Şahin and Valletta (2011a), Mulligan (2012b), Restrepo (2015), Farber (2015), and Ravn and Sterk (2012).

\subsection{The zero lower bound}

The policy of every modern central bank is to issue two types of debt: reserves and currency. The bank pays interest or collects negative interest on reserves. No direct force constrains the rate on reserves. It is impractical to pay or collect interest on currency. Central banks keep currency and reserves at par with each other by standing ready to exchange currency for reserves or reserves for currency in unlimited amounts. If the bank sets a reserve rate below the negative of the storage cost of currency, owners of reserves will convert them to higher-yielding currency. A number of European central banks have experimented recently with increasingly negative reserve rates.

The lower bound on the real interest rate is the bound on the nominal rate less the expected rate of inflation. Figure 15 shows three time series relevant for measuring expected inflation. The top line is the median expected rate of inflation over the coming year for the Michigan Survey of Consumers. The line starting in 2007 is the median forecast of the average annual rate of change of the PCE price index over the coming 5 years, in the Survey of Professional Forecasters of the Philadelphia Federal Reserve Bank. The bottom line is the breakeven inflation rate in the 5-year TIPSs and nominal 5-year note - the rate of inflation that equates the nominal yields of the two instruments. See also Fleckenstein, Longstaff and Lustig (2013) on extracting expected inflation from inflation swaps.

The three measures agree that essentially nothing happened to expected inflation over the period of the post-crisis slump. All recorded a drop around the time of the crisis, but 


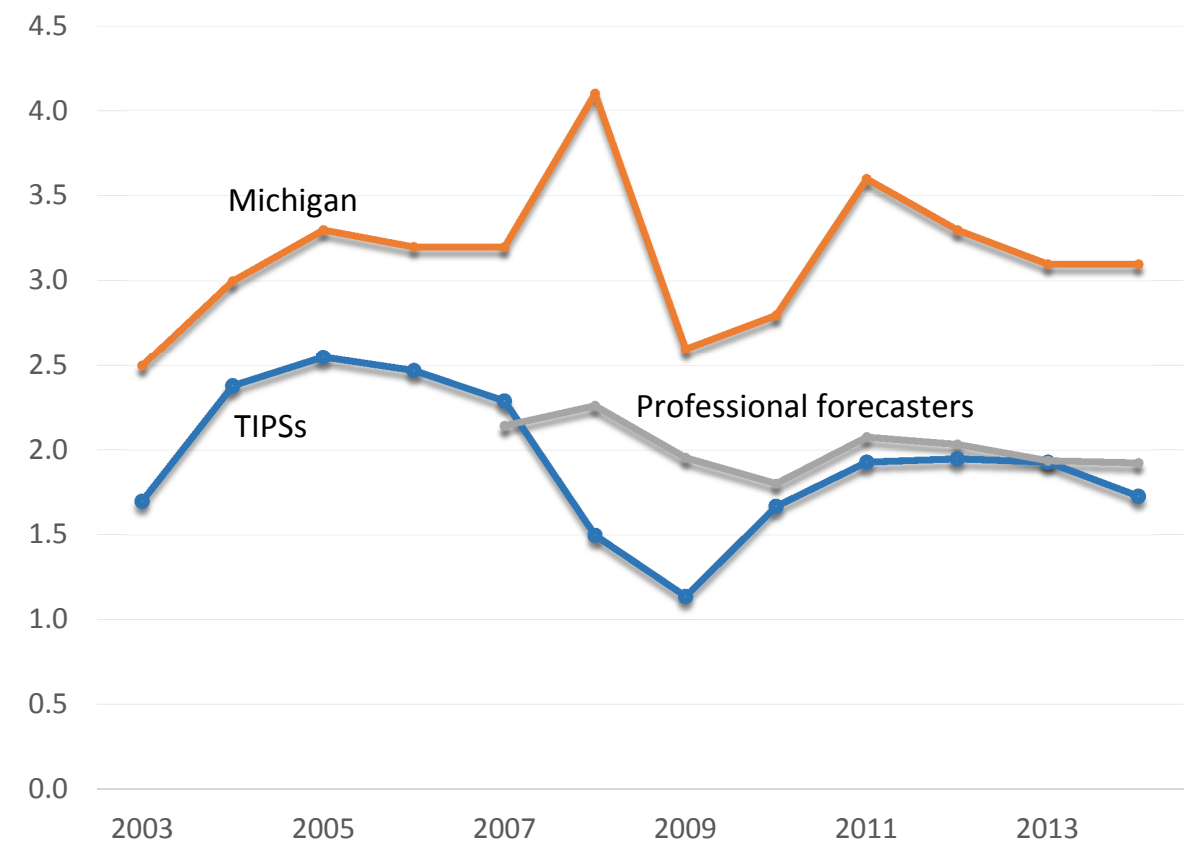

Figure 15: Inflation Expectations and Forecasts

then returned to close to pre-crisis levels despite high unemployment. This finding pretty much eliminates an idea that permeated macroeconomics over the past 50 years, that slack more or less automatically results in lower inflation. Some combination of factors in 2008 prevented the collapse of the price level that occurred, for example, in the much deeper slump following the contraction of 1929 to 1933.

Had expected inflation declined by the amounts that occurred in the earlier slumps of the past 50 years, the influence of the zero lower bound on the real interest rate would have been more severe. And if deflation at the rate experienced in 1929 to 1933 had occurred, a catastrophe similar to the Great Depression would probably have occurred. Good fortune kept expected inflation at normal levels and avoided high real interest rates and their likely adverse effects on output and employment.

In view of the importance of the inflation rate in determining the real interest rate corresponding to a zero nominal rate, the complete absence of a model of inflation is a considerable shortcoming of current macroeconomic thinking. About the best that macro modeling can do is to take expected inflation as an exogenous constant, currently around two percent. It is common for macroeconomists to say that "inflation is firmly anchored at the Fed's target of two percent" as if that amounted to a model. But it's not - at best 
it is an observation that expected inflation has remained at about that level despite large changes in output, employment, and other macro variables.

With exogenous, constant inflation, the bound on the nominal interest rate places a bound on the safe real rate at the nominal bound minus the rate of inflation-minus two percent in the recent slump if the nominal bound is zero; minus three percent if the nominal bound is minus one percent.

Stock and Watson (2010) study the joint behavior of inflation and unemployment with conclusions similar to those stated here. Ball and Mazumder (2011) argue in favor of the conventional view that inflation has a stable relation to slack.

\subsubsection{Incorporating the zero lower bound in macro models}

Hall (2011b) discusses the issues in modeling an economy with a safe real rate fixed above the value that would clear the output market under normal conditions. In brief, the high real rate creates the illusion of an opportunity to defer consumption spending when deferral is actually infeasible. Because of the mispricing of the benefit of saving, consumers create congestion as they try to save and defer spending. Congestion arises from the same force that slows traffic on a highway that is underpriced, so more drivers try to use it than its capacity. As a practical matter, the congestion appears to take the form of low job-finding rates and abnormally high unemployment.

Modeling of the congestion resulting from the mispricing of saving is still at a formative stage. To frame the issue, consider a simple frictionless general-equilibrium macro model with a unique equilibrium. The model will describe an equilibrium value of the short-term safe real interest rate. Now implant a central bank in the model with a policy of setting that rate at a value above the equilibrium value. In particular, suppose that the bank's interest rate is elevated by the zero lower bound. What happens in the model? It cannot have an equilibrium - its only equilibrium is ruled out by assumption. One solution in macro theory is to disable one equation. Then the model has one less endogenous variable, the interest rate (made exogenous by the zero lower bound), and one less equation. One example is to drop a clearing condition for the labor market and to interpret the gap between labor supply and labor demand as unemployment. When the central bank sets a rate above equilibrium, labor demand will fall short of labor supply and unemployment will be above its normal level. This approach has some practical appeal and often gives reasonable answers. 
A closely related approach is to place the demand gap in the product market. Krugman (1998) and Korinek and Simsek (2014) are examples of that approach. Farhi and Werning (2013) present a general analysis of demand gaps, where any set of prices and wages can be jointly restricted and gaps can occur in any market.

The New Keynesian tradition takes a different and more subtle approach to this issue by adding the price level as another endogenous variable without any corresponding equation. The model has demand gaps in the product market associated with temporarily sticky prices that adjust over time to close the gaps. Eggertsson and Krugman (2012) and Christiano, Eichenbaum and Rebelo (2011) apply the NK model to the zero lower bound issue. One branch of the NK literature - notably Walsh (2003), Gertler et al. (2008), and, most recently, Christiano et al. (2016) - uses the Diamond-Mortensen-Pissarides framework to describe the labor market, so the only role of demand gaps is in the product market.

Hall (2016) tackles the congestion issue directly, in the DMP setup. Both the output and labor markets suffer from congestion when the central bank elevates the real rate above the market-clearing level. The central bank's acceptance of deposits at the elevated real rate creates an outside option in the product-price bargain that creates slack according to standard DMP principles.

In general, a model that combines the DMP view of unemployment with a real interest rate held above its market-clearing level will incorporate an additional variable, analogous to congestion in the highway case, that changes the DMP unemployment rate and the demandgap rate until they are equal. To be concrete about that variable, suppose it is matching efficiency. A decline in efficiency increases hiring cost, raises the cost of labor, lowers the demand for labor, and raises demand-gap unemployment. The decline in efficiency lowers the job-finding rate and raises the DMP unemployment rate. The second effect is robust in the DMP model and presumably exceeds the effect on demand-gap unemployment. In equilibrium, unemployment is less than demand-gap unemployment would be at normal matching efficiency but higher than DMP unemployment would be at normal efficiency. The model would need to tie matching efficiency to the spread between the bank's interest rate and the rate that cleared the output and labor markets. Though this mechanism is attractive because matching efficiency did fall after the 2008 crisis, I do not have a model embodying variations in matching efficiency. The model in Hall (2016) is rather more complicated and invokes DMP principles in both product and labor markets. 
If the effect of congestion in the labor market on labor demand is small enough to be neglected, the gap between labor supply and labor demand controls unemployment. In this case, the traditional view that ignores DMP-type considerations applies. In that case, the general-equilibrium model simply omits the DMP-based equations. In the background, labor-market congestion fluctuates to bring unemployment into line with the level dictated by product demand. In the model later in this chapter, I take this approach as an interim solution pending development of fully articulated models of congestion induced by aboveequilibrium real interest rates.

Michaillat and Saez (2014) build a model of labor- market congestion that differs from the DMP model in one crucial respect - it lacks a resource decision to control the tightness of the market. In the DMP model, recruiting effort determines the tightness of the labor market. Employers expand recruiting effort until the payoff to creating an incremental vacancy equals the expected recruiting cost. In a simple real business-style macro model with a DMP labor market, equilibrium is determinate. By contrast, in the model of Michaillat and Saez, the corresponding basic model is indeterminate. It has a continuum of equilibria indexed by the real interest rate, with tightness depending on that rate. A monetary intervention that sets the real interest rate picks out one of those equilibria. Adding that monetary intervention to the DMP-based model would make it over-determined.

This discussion presupposes that the central bank can set any path it chooses for the real interest rate. Friedman (1968) reached the opposite conclusion. In his view, a bank that tried to keep the real rate below the market-clearing level would cause exploding inflation (the case that concerned him in 1967), and a policy aiming to keep the real rate above the market-clearing level presumably would cause exploding deflation. Recent experience does not bear his prediction out - the lower bound froze the safe real rate at around minus two percent because expected inflation remained unchanged at around two percent per year. Our lack of understanding of inflation stands in the way of fully satisfactory modeling of central bank policies that control the real interest rate.

See also Attanasio and Weber (1995), Correia, Farhi, Nicolini and Teles (2010), Eggertsson and Krugman (2012), Cochrane (2014), Hall (2016), and Eggertsson and Mehrotra (2014). 


\subsubsection{The zero lower bound and product demand}

The zero lower bound, together with low expected inflation, has prevented central banks from lowering interest rates as much as would seem appropriate. Lower rates should stimulate output and employment. The Federal Reserve and the Bank of Japan have kept rates slightly positive since the crisis, while the European Central Bank did the same until recently, when it pushed the rate just slightly negative. All three economies had combinations of high unemployment and substandard inflation that unambiguously called for lower rates, according to standard principles of modern monetary economics. Under normal conditions, fluctuations in product demand are not a source of important fluctuations in output and employment, because interest rates change as needed to clear those markets. Under almost any view of purposeful monetary policy, the central bank adjusts its policy rate to in response to those demand fluctuations. But the zero lower bound is an exception to that principle. Economies with low inflation rates and low equilibrium real interest rates run the danger of episodic slumps when the lower bound is binding.

In the slump that began in 2008, three driving forces for product demand appeared to be important: rising discounts, tightening lending standards to businesses, and tightening lending standards to households. All three of these declines may also reflect the rising importance of another driving force, financial frictions. Other sources could be declining government purchases and transfers and declining export demand. In the recent slump, government purchases fell slightly relative to trend, transfers rose dramatically, and exports fell.

\subsubsection{Discounts}

As documented elsewhere in this section, discounts applied to future risky cash flows appeared to rise dramatically during and immediately after the financial crisis. Basic principles of investment theory hold that purchases of new capital goods decline when discounts rise. In fact, all three major categories of investment fell sharply: (1) business purchases of new plant, equipment, and intellectual property, (2) residential construction, and (3) autos and other consumer durables. Eggertsson and Krugman (2012) describe how a rise in discounts pushes the economy into a regime where the zero lower bound binds. 


\subsubsection{Lending standards to businesses}

Survey data show unambiguously that bank officials believe that they tightened lending standards after the crisis. It remains controversial whether the tightening is an independent driving force or just a symptom of other adverse forces. Chodorow-Reich (2014), using data on individual bank-borrower relationships, argues for a separate role for tightening standards. Tighter standards may also be a driving force for the sharp decline in residential construction, given the dependence of major house-builders on bank lending.

\subsubsection{Lending standards to households}

I noted earlier that rising lending standards and declining equity resulted in cutbacks in consumption because families who had previously financed high consumption levels in part by taking on more and more debt could no longer qualify for those loans.

\section{Fiscal Driving Force and Multiplier}

The multiplier is the derivative of total GDP or a component, such as consumption, with respect to an exogenous shift in product demand. The obvious source of such a shift is government purchases, but the same multiplier describes the propagation of other shifts in product demand, notably those induced by changes in household access to credit.

Ramey (2011a) is a recent survey of the literature on the multiplier, and her chapter in this volume also treats the subject in detail. See also Coenen, Erceg, Freedman, Furceri, Kumhof, Lalonde, Laxton, Lind, Mourougane, Muir, Mursula, de Resende, Roberts, Roeger, Snudden, Trabandt and in’t Veld (2012), Shapiro and Slemrod (2009), Spilimbergo, Symansky and

Schindler (2009), Hall (2009), Barro and Redlick (2011), Parker, Souleles, Johnson and McClelland (2011), Kaplan and Violante (2014), and Ramey (2011b).

\section{$5 \quad$ Other Issues}

\subsection{Decline in the labor share}

Economists have pursued multiple explanations of the decline, but no consensus has formed. Rognlie (2015) provides a comprehensive discussion of this topic. See also Karabarbounis and Neiman (2014). 


\begin{tabular}{lcccccc}
\hline \hline & $\begin{array}{c}\text { Personal } \\
\text { care }\end{array}$ & $\begin{array}{c}\text { Household } \\
\text { work }\end{array}$ & $\begin{array}{c}\text { Market } \\
\text { work }\end{array}$ & Education & Leisure & Other \\
\hline Men & 1.3 & 0.1 & -2.5 & 0.2 & 1.3 & -0.4 \\
Women & 1.6 & -0.7 & -0.8 & -0.1 & 0.8 & -0.8 \\
\hline \hline
\end{tabular}

Table 2: Changes in weekly hours of time use, 2003 to 2013, people 15 and older

\subsection{Time Use}

Some indication about the changing balance between work and other uses of time comes from the American Time Use Survey, which began in 2003. Table 2 shows the change in weekly hours between 2003 and 2013 in a variety of activities. For men, the biggest change by far is the decline of 2.5 hours per week at work, a big drop relative to a normal 40-hour work week. A small part of the decline is attributable to higher unemployment - the unemployment rate was 6.0 percent in 2003 and 7.4 percent in 2013. The decline for women is much smaller, at 0.8 hours per week. For both sexes, the big increases were in personal care (including sleep) and leisure (mainly video-related activities). Essentially no change occurred in time spent in education. Women cut time spent on housework. See also Aguiar, Hurst and Karabarbounis (2013).

\section{$6 \quad$ A Model}

Many macro-fluctuations models omit slower-moving driving forces and are correspondingly estimated or calibrated to data filtered to remove slower movements. Growth models generally omit cyclical and medium-frequency driving forces. A small literature - notably including Comin and Gertler (2006) - deals explicitly with medium-frequency driving forces and corresponding movements of key macro variables. That paper focuses on technology and productivity. The model developed here considers other medium-frequency driving forces, such as labor-force participation and discounts. Hall (2005) discusses evidence of the importance of medium-frequency movements and argues against the suitability of superimposing a high-frequency business-cycle model on an underlying growth model. Instead, a unified model appears to be a better approach. 
The model is inherently non-stationary-its labor force grows randomly and so does productivity. Solution methods widely used for stochastic macro models, either near-exact solutions using projection methods or approximate solutions based on log-linearization, require that models be restated in stationary form. I take a different approach. The model has random driving forces that are functions of a Markov discrete state. Over a finite horizon the model has an event space with a large but finite set of nodes. Models with this structure are widely used in finance and banking. I find essentially exact solutions for the contingent values of continuous state variables and other key macro variables at each node. Finance models, such as the binary option-pricing model, have backward-recursive solutions, but macro models require solving the entire model as a system of simultaneous equations. Recursive models are highly sparse, and solution methods that fully exploit the sparsity are fast.

\subsection{Specification}

The equations of the model are the familiar first-order conditions for optimization by the decision makers in the model and laws of motion of the state variables, together with initial and terminal conditions. The framework does not require that the model be recursive, though the model here is actually recursive - it can be expressed in equations that consider only three dates: Now (for example, $k$ ), Soon (for example, $k^{\prime}$ ), and Later (for example, $k^{\prime \prime}$ ). Each value Now branches stochastically into $N_{t}$ values in the Soon period and $N_{t}^{2}$ values in the Later period. Here $N_{t}$ is the number of states in the discrete Markov process in period t. The economy operates for $T$ periods.

The driving forces of the model are:

$a$ : increment to total factor productivity

$l$ : increment to the labor force

$d_{k}$ : discount or confidence with respect to capital

$d_{n}$ : discount or confidence with respect to job creation

$d_{f}$ : discount or flight to safety factor with respect to safe one-year returns (found to be negative, implying a safety premium)

$z$ : product-market wedge arising from market power

$g$ : government purchases of goods and services, serving as a proxy for shifts in product de- 
mand arising from forces not considered explicitly in the model

The continuous state variables are:

$k$ : physical capital stock (endogenous)

$A$ : total factor productivity (exogenous)

$L$ : labor force (exogenous)

Endogenous variables that are functions of the state variables are:

$y$ : output

$n$ : employment

$c$ : consumption

$q$ : Tobin's $q$, the value of installed capital

$r^{\prime}$ : the realized return to holding installed capital from now to later

$r_{f}$ : the safe real interest rate from now to later, known now

$m$ : the stochastic discounter, not including $d_{k}, d_{n}$, and $d_{f}$

$x$ : the marginal revenue product of labor

\section{$6.2 \quad$ States}

An integer-valued state $s$ governs the outcomes of random influences on the economy. It follows a Markov process:

$$
\operatorname{Prob}\left[s^{\prime} \mid s\right]=\pi_{s, s^{\prime}}
$$

\subsection{Technology}

Output at the beginning of a period combines labor and capital services according to a Cobb-Douglas technology:

$$
y^{\prime}=A^{\prime} n^{1-\alpha} k^{\alpha}
$$

Installation of capital incurs quadratic adjustment costs. The marginal cost of adjustment, $q$, is

$$
q^{\prime}=\kappa\left(\frac{k^{\prime}}{k}-1\right)+1
$$


Total factor productivity evolves as

$$
A^{\prime}=\exp \left(a_{s^{\prime}}\right) A
$$

Here $a_{s^{\prime}}$ is a state-dependent log-increment to TFP. The law of motion of the capital stock is

$$
k^{\prime}=(1-\delta) k+y^{\prime}-c^{\prime}-g^{\prime}
$$

Here $\delta$ is the rate of depreciation of capital.

\subsection{Financial markets}

The realized rate of return to holding capital is

$$
r_{k}^{\prime}=\frac{\alpha \frac{y^{\prime}}{z^{\prime} k}+(1-\delta) q^{\prime}}{q}-1 .
$$

Here $z$ is a product-marked wedge. The economy's normal stochastic discount factor is

$$
m^{\prime}=\beta\left(\frac{c^{\prime}}{c}\right)^{-1 / \sigma}
$$

The pricing condition for the return to capital is

$$
\mathbb{E}\left[\left(1+r_{k}^{\prime}\right) m^{\prime}\right]-d_{k}=1
$$

Here $d_{k}$ is a distortion of the discounter for the return to capital, interpreted as loss of confidence or increased pessimism, that lowers the perceived present value of the future payoff to capital.

The pricing condition for the risk-free rate is

$$
\left.\mathbb{E}\left[\left(1+r_{f}\right) m^{\prime}\right)\right]-d_{f}=1
$$

Here $d_{f}$ is a distortion of the discounter for the safe real return, whose negative value is interpreted as a liquidity premium or flight to safety premium.

\subsection{The zero lower bound}

The model does not embody a bound on the short safe interest rate. Rather, it identifies conditions when the rate is low-generally negative. Times of negative rates are times when the lower bound would be binding, and the model's equilibrium would not actually hold. As 
noted earlier, macroeconomics has yet to provide a coherent account of equilibrium with a binding lower bound. All the literature simply assumes that a demand gap implies output and employment gaps, without further explanation of why economic behavior results in gaps. The predictions of the demand-gap model may well be correct - the point is that models don't meet normal standards of explanation imposed on modeling other economic phenomena. See Hall (2016) for further discussion of this point.

\subsection{Initial and terminal values of the capital stock}

The capital stock grows stochastically along with growth in TFP, $A$, and the labor force, $L$. I calculate the initial capital stock and the stock at each terminal node as

$$
k^{*}=\left(1-u^{*}\right) L\left(\frac{\alpha A}{r^{*}+\delta}\right)^{1 /(1-\alpha)} .
$$

Here $u^{*}$ is the normal unemployment rate. The quantity $r^{*}$ is the constant discount rate equivalent to actual stochastic discounting, including the extra discount $d_{k}$. I pick the value of $r^{*}$ that generates roughly constant growth of capital. If $r^{*}$ is below that level, the capital stock grows more rapidly at first until it reaches the stochastic turnpike path, then shrinks back to the terminal condition toward the end. The stock sags below its initial level and grows extra-rapidly at the end of the period if $r^{*}$ is too high.

\subsection{The labor market}

The model incorporates the idea that hiring is a form of investment, as in the DiamondMortensen-Pissarides model of the labor market. As with other forms of investment, the discount rate influences hiring, as discussed with citations in Hall (2015). The equation also takes the marginal revenue product of labor as the measure of the benefit of a hire - subject to variation through changes in market power as in Rotemberg and Woodford (1999), stated in DMP terms in Walsh (2003).

DMP employment depends on the present value of the ratio, $x^{\prime} / \bar{x}^{\prime}$ of the actual future marginal revenue product of labor to the normal level based on future technology $A^{\prime}$ and current capital $k$. The numerator is

$$
x^{\prime}=(1-\alpha) A^{\prime}\left(\frac{k}{z^{\prime} n}\right)^{\alpha}
$$

and the denominator is

$$
\bar{x}^{\prime}=(1-\alpha) A^{\prime}\left(\frac{k}{\bar{n}}\right)^{\alpha} .
$$


There is a downward distortion, $d_{n}$, in the discounted value of the ratio. Employment is

$$
\begin{aligned}
n & =\bar{n}\left[\frac{\mathbb{E}\left(m^{\prime} x^{\prime}\right)}{\mathbb{E}\left(m^{\prime} \bar{x}^{\prime}\right)} \exp \left(-d_{n}\right)\right]^{\omega} \\
& =\bar{n}\left[\left(\frac{\bar{n}}{z n}\right)^{\alpha} \exp \left(-d_{n}\right)\right]^{\omega}
\end{aligned}
$$

The value of $d_{n}$ implied by the data is

$$
d_{n}=-\left(\alpha+\frac{1}{\omega}\right) \log \frac{n}{\bar{n}}-\alpha \log z
$$

Given $d_{n}$, the resulting solution is

$$
\log \frac{n}{\bar{n}}=-\left(\frac{\omega}{1+\alpha \omega}\right)\left(\alpha \log z+d_{n}\right) .
$$

The labor force evolves as

$$
L^{\prime}=\exp \left(l_{s^{\prime}}\right) L
$$

Unemployment is

$$
n=(1-u) L
$$

\subsection{Timing}

Timing is easiest to understand in the non-stochastic case, where $N_{t}=1$ for all periods $t$. In period 1 , capital is at its specified initial value $k_{I}$. No consumption occurs in period 1 . In period $T$, capital is at its specified terminal value, $k_{T}$. No employment occurs. Consumption $c_{T}$ is an unknown to be determined. Thus there are $T-2$ values of capital to be determined, $k_{2}$ through $k_{T-1}$, and $T-1$ values of consumption, $c_{2}$ through $c_{T}$. Given candidate values for these, and the exogenous variables $A_{t}$ and $L_{t}$, one can calculate corresponding candidate values of the other variables, $y_{t}, q_{t}, r_{k, t}, m_{t, t+1}, x_{t}, n_{t}$, and $u_{t}$. The $T-1$ residuals of the material balance condition,

$$
\epsilon_{M, t}=k^{\prime}-\left[y^{\prime}+(1-\delta) k-c^{\prime}-g^{\prime}\right], t=1: T-1,
$$

and the $T-2$ residuals of the Euler equation,

$$
\epsilon_{E, t}=\mathbb{E}_{t}\left(1+r_{k, t+1}\right)\left(m_{t, t+1}-d_{t}\right)-1, t=2: T-1
$$

define a system of equations

$$
\epsilon(x)=0 .
$$

Here $\epsilon(x)$ is the combined vector of the $2 T-3$ residuals and $x$ is a vector of the $2 T-3$ unknown values of $k_{t}$ and $c_{t}$. A standard nonlinear equation solver finds a solution, which is the dynamic stochastic contingent equilibrium of the model. 


\subsection{Summary}

Equations with a zero on the right-hand side enter the solution with discrepancies $\epsilon$ which are driven to zero by Newton's method.

$$
\begin{gathered}
\operatorname{Prob}\left[s^{\prime} \mid s\right]=\pi_{s, s^{\prime}} . \\
k^{\prime}-(1-\delta) k-y^{\prime}+c^{\prime}+g^{\prime}=0 . \\
A^{\prime}=\exp (a) A . \\
L^{\prime}=\exp (l) L .
\end{gathered}
$$

$$
y^{\prime}=A^{\prime} n^{1-\alpha} k^{\alpha}
$$

$$
q^{\prime}=\kappa\left(\frac{k^{\prime}}{k}-1\right)+1
$$$$
r_{k}^{\prime}=\frac{\alpha \frac{y^{\prime}}{z k}+(1-\delta) q^{\prime}}{q}-f^{\prime}-1 .
$$$$
m^{\prime}=\beta\left(\frac{c^{\prime}}{c}\right)^{-1 / \sigma}
$$

$$
x^{\prime}=(1-\alpha) \frac{y^{\prime}}{z n}
$$

$\mathbb{E}\left[\left(1+r_{k}^{\prime}\right)\left(m^{\prime}-d\right)\right]-1=0$

$$
\begin{gathered}
r_{f}=\frac{1}{\mathbb{E} m^{\prime}}-1 . \\
n=(1-u) L .
\end{gathered}
$$




$$
\log \frac{n}{\bar{n}}=\left(\frac{\omega}{1+\alpha \omega}\right)\left(\alpha \log \frac{k}{z \bar{k}}-d_{n}\right) .
$$

\section{Application to the U.S. Economy}

\subsection{States of the economy}

The model operates at an annual frequency. I constructed its states by the $k$-cluster method with 6 clusters, based on the following variables measured over the period from 1953 through 2014:

- TFP growth, from Fernald (2012), without utilization adjustment

- The discount implicit in the S\&P stock-market index, measured as the expected real return based on the Livingston survey.

- The annual growth rate of the civilian labor force

- The unemployment rate

Table 3 shows the discrete states of the model, in terms of the values of the four variables. It also shows the classification of years by state. Each of the four variables defining the states has six state-dependent values. In a row in the table, Low refers to the two lowest values of a variable across the states, Med to the middle two values, and High to the upper two values. Table 4 shows the state-contingent values of the variables that define the states. The states are:

1. Strong economy with low discount, low unemployment, high growth of labor force, high productivity growth

2. Strong economy with medium TFP growth

3. Mediocre economy with low TFP growth

4. Mediocre economy with high discount and low TFP growth

5. Slump with average TFP growth 


\begin{tabular}{|c|c|c|c|c|c|}
\hline State & $\begin{array}{l}\text { TFP } \\
\text { growth }\end{array}$ & Discount & $\begin{array}{l}\text { Labor-force } \\
\text { growth }\end{array}$ & $\begin{array}{l}\text { Unemploy- } \\
\text { ment }\end{array}$ & Years in state \\
\hline 1 & Low & Low & High & High & $\begin{array}{l}\text { 1955, 1957, 1959, 1960, 1964, 1966, } \\
\text { 1968, 1969, 1972, 1995, 1996, 1997, } \\
\text { 1999, 2000, } 2006\end{array}$ \\
\hline 2 & Low & Low & High & Med & $\begin{array}{l}\text { 1953, 1956, 1962, 1965, 1973, 1978, } \\
1988,1989,1998\end{array}$ \\
\hline 3 & Med & Med & Med & Low & $\begin{array}{l}\text { 1954, 1958, 1963, 1967, 1971, } 1977, \\
\text { 1979, 1980, 1985, 1986, 1987, 1990, } \\
1991,1993,1994,2007,2013,2014\end{array}$ \\
\hline 4 & High & Med & Med & Low & $\begin{array}{l}1961,1970,1974,1975,1981,1982, \\
1983,2001,2002,2004,2005,2008\end{array}$ \\
\hline 5 & High & High & Low & Med & 2003,2009 \\
\hline 6 & Med & High & Low & High & 1976, 1984, 1992, 2010, 2011, 2012 \\
\hline
\end{tabular}

Table 3: The States of the Model

\begin{tabular}{ccccc}
\hline \hline & \multicolumn{4}{c}{ State-contingent value, percent } \\
\cline { 2 - 5 } State & Discount & $\begin{array}{c}\text { Unemploy- } \\
\text { ment }\end{array}$ & $\begin{array}{c}\text { Labor- } \\
\text { force } \\
\text { growth }\end{array}$ & $\begin{array}{c}\text { TFP } \\
\text { growth }\end{array}$ \\
\hline 1 & 2.79 & 4.67 & 1.68 & 2.00 \\
2 & -1.84 & 4.81 & 1.79 & 1.80 \\
3 & 5.40 & 6.22 & 1.48 & 0.43 \\
4 & 10.73 & 6.63 & 1.40 & 0.27 \\
5 & 20.74 & 7.63 & 0.52 & 0.92 \\
6 & 3.94 & 8.22 & 1.03 & 2.42 \\
\hline \hline
\end{tabular}

Table 4: State-Contingent Values of the Variables Defining the States 


\begin{tabular}{|c|c|c|c|c|c|c|c|c|}
\hline & & \multicolumn{6}{|c|}{ To state } & \multirow{2}{*}{$\begin{array}{c}\text { Ergodic } \\
\text { probability }\end{array}$} \\
\hline & & 1 & 2 & 3 & 4 & 5 & 6 & \\
\hline \multirow{6}{*}{$\begin{array}{l}\text { From } \\
\text { state }\end{array}$} & 1 & 0.33 & 0.27 & 0.20 & 0.20 & 0.00 & 0.00 & 0.25 \\
\hline & 2 & 0.33 & 0.11 & 0.44 & 0.11 & 0.00 & 0.00 & 0.13 \\
\hline & 3 & 0.35 & 0.12 & 0.35 & 0.12 & 0.00 & 0.06 & 0.30 \\
\hline & 4 & 0.08 & 0.08 & 0.08 & 0.42 & 0.17 & 0.17 & 0.20 \\
\hline & 5 & 0.00 & 0.00 & 0.00 & 0.50 & 0.00 & 0.50 & 0.03 \\
\hline & 6 & 0.00 & 0.00 & 0.67 & 0.00 & 0.00 & 0.33 & 0.10 \\
\hline
\end{tabular}

Table 5: Transition Matrix and Ergodic Distribution

\section{Slump with high TFP growth}

Table 5 shows the annual transition matrix among the four states together with the ergodic probabilities of the states. Figure 16 illustrates the persistence of the six states. It shows the expected value of the unemployment rate starting in each of the six states and evolving toward the ergodic distribution over a 10-year period. For example, the curve labeled 6 shows unemployment starting at the state-contingent level for state 6 , which is over 8 percent. The rate falls quickly, dropping slightly below its ergodic value before converging back to that value. In the first few years, the dynamics of these impulse response functions differ, corresponding to the differences in the rows of the transition matrix. In later years, the paths are similar, because they are all controlled by the largest eigenvalue of the transition matrix.

The model starts in period 1 with initial values of TFP and the labor force both equal to one. In the base case, the distribution of the state in period 2 is the ergodic distribution. For four years, the transition matrix governs the succeeding states. In year 5, the economy has $6^{4}=1296$ possible configurations. For the next ten years, the economy continues to evolve, but no further random events occur. The exogenous variables-TFP and the labor force -grow at constant rates equal to the average of the state-contingent rates, weighted by the ergodic distribution. The model has $1+6+36+216+1296+10 \times 1296=14,515$ nodes, each with distinct values of all the variables of the model. 


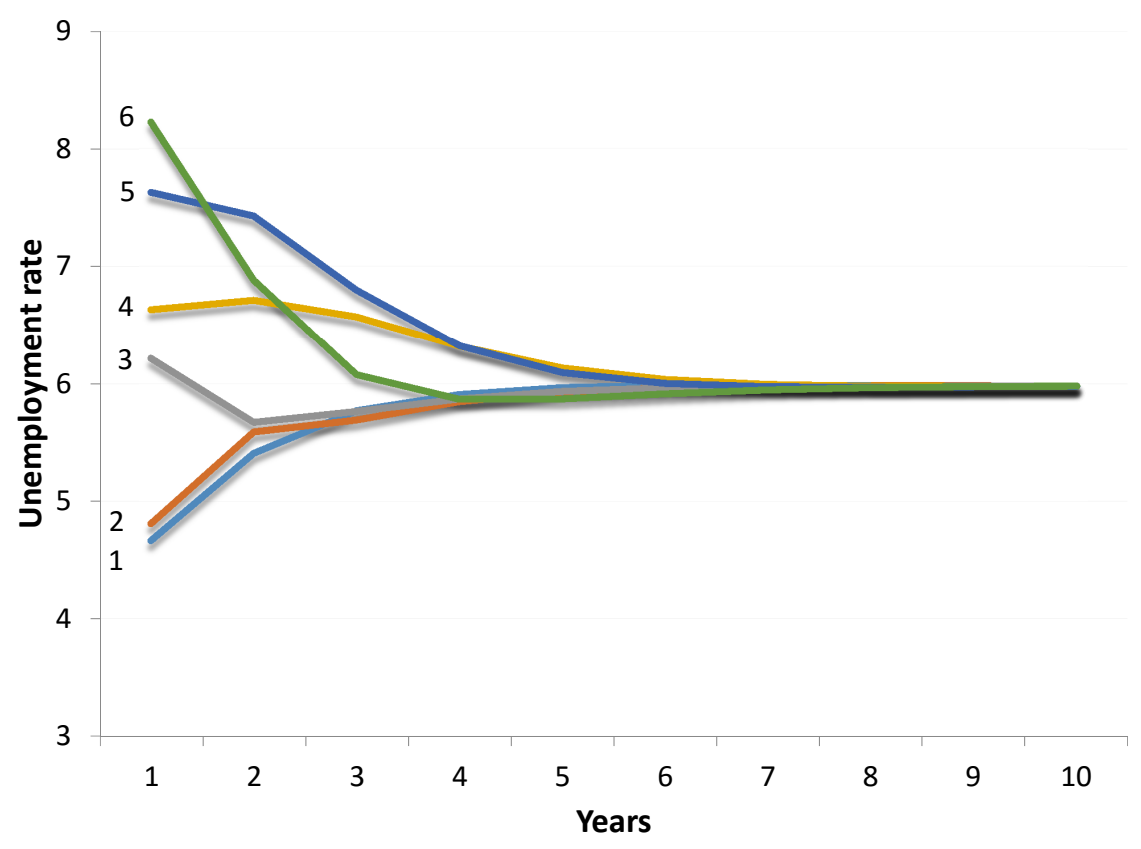

Figure 16: Persistence of the States

\section{2 $\quad$ State-based driving forces}

Two of the variables used to define the states are also treated as driving forces in the model. These are the increments to TFP and the labor force. Another two driving forces are calculated from the data. These are the discount shock for capital, calculated as the residual in the pricing condition for capital,

$$
d_{k}=\mathbb{E}\left[\left(1+r_{k}^{\prime}\right) m^{\prime}\right]-1,
$$

averaged over states to measure the expectation, and the discount shock for job-creation, calculated as

$$
d_{n}=-\left(\alpha+\frac{1}{\omega}\right) \log \frac{n}{\bar{n}} .
$$

I also calculate the values of the discount shock for the safe one-year interest rate, as

$$
d_{f}=\mathbb{E}\left[\left(1+r_{f}\right) m^{\prime}\right]-1,
$$

but this value does not feed back into the rest of the model, so it is not a driving force, provided no bound on the rate is binding. Table 6 shows the state-contingent values of the driving forces.

TFP growth varies substantially across the economy's states. It is generally higher in the better, lower-numbered, states, but is highest in state 6 . The reason is that most of the 


\begin{tabular}{cccccc}
\hline \hline & \multicolumn{5}{c}{ State-contingent value, percent } \\
\cline { 2 - 6 } State & $\begin{array}{c}\text { TFP } \\
\text { growth }\end{array}$ & $\begin{array}{c}\text { Labor- } \\
\text { force } \\
\text { growth }\end{array}$ & $\begin{array}{c}\text { Capital } \\
\text { discount }\end{array}$ & $\begin{array}{c}\text { Liquidity } \\
\text { discount }\end{array}$ & $\begin{array}{c}\text { Labor } \\
\text { discount }\end{array}$ \\
\hline 1 & 2.00 & 1.68 & 15.01 & -1.09 & -0.81 \\
2 & 1.80 & 1.79 & 14.93 & -1.23 & -0.72 \\
3 & 0.43 & 1.48 & 13.39 & -2.25 & 0.17 \\
4 & 0.27 & 1.40 & 12.14 & -0.90 & 0.44 \\
5 & 0.92 & 0.52 & 12.98 & -4.87 & 1.08 \\
6 & 2.42 & 1.03 & 14.25 & -3.05 & 1.46 \\
\hline \hline
\end{tabular}

Table 6: Values of the Driving Forces

years classified into state 6 are in the later years of slumps, when the economy is recovering. Historically, recoveries enjoyed high measured TFP growth because of improving utilization (recall that the model uses Fernald's TFP measure without his utilization adjustment). Labor-force growth, a driving force omitted from most models of fluctuations, also shows substantial variability across states, in a pattern similar to TFP. The capital discount is high, definitely in excess of almost all measures of the equity premium. The reason is that it includes factors that cause the return to capital to exceed the payout to owners that are not normally included in the equity premium. These include corporate taxes and agency frictions. The capital discount is higher in the favorable, lower-numbered states, again with the exception of state 6 , so it is not much of a contributor to the business cycle. The table shows the calculated values of the liquidity discount, though it is not actually a driving force. The negative of the discount is a safety premium, associated with liquidity services and, in the bad states, a flight to safety. The most negative value of the discount is in the rare state 5 when the economy is in an unusually bad condition. That fact is important for the model's message about the conditions when the zero lower bound on the safe rate will matter. Finally, the labor discount, calculated from the unemployment rate, naturally tracks unemployment perfectly, because the other determinant of unemployment in the model, the product-market wedge, is taken to be the same in all states, for want of a reliable basis for computing it.

Two additional driving forces are present in the model, but do not have empirical counterparts. These are the product-market wedge, $z$, and the variable $g$, interpreted as a shift in product demand. The product-market wedge plays a central role in the New Keynesian model, but measurement has proven controversial. Shifts in product demand resulting from 


\begin{tabular}{|c|c|c|}
\hline Parameter & Interpretation & Value \\
\hline$\alpha$ & $\begin{array}{l}\text { Elasticity of output with respect } \\
\text { to capital }\end{array}$ & 0.35 \\
\hline$\delta$ & Depreciation rate of capital & 0.1 \\
\hline$\beta$ & Household discount ratio & 0.95 \\
\hline$\sigma$ & $\begin{array}{l}\text { Intertemporal elasticity of } \\
\text { substitution }\end{array}$ & 0.5 \\
\hline$\kappa$ & Capital adjustment parameter & 2 \\
\hline$u^{*}$ & Normal unemployment rate & 0.0596 \\
\hline$\omega$ & $\begin{array}{l}\text { Elasticity of employment } \\
\text { function with respect to present } \\
\text { value of a worker's contribution }\end{array}$ & 4 \\
\hline$r k^{*}$ & $\begin{array}{l}\text { Effective discount rate for initial } \\
\text { and terminal capital }\end{array}$ & 0.3 \\
\hline
\end{tabular}

Table 7: Parameter Values

tightening financial constraints on consumption have played a big role in understanding the financial crisis of 2008 and its aftermath, but again measurement of the shifts has proven controversial. The model tracks the effects of $z$ and $g$, but its base case does not include their actual movements as driving forces in the economy. They both play important roles in the application of the model to the crisis of 2008 and the ensuing slump.

\subsection{Parameters}

Table 7 shows the parameter values used in the model. All are standard except for $r_{k}^{*}$, which is special to this framework, to ensure that the model's initial and terminal capital are close to its turnpike level of capital in relation to TFP and the size of the labor force.

\subsection{Equilibrium}

An equilibrium of the model is a complete set of values of the variables at every node. Figure 17 provides some basic information about the equilibrium - it shows the means and standard deviations of the two exogenous variables, TFP and the size of the labor force, and two key endogenous variables, consumption and the unemployment rate, in each year. The distributions are conditional on the state of the economy in the first year. The standard deviations are calculated across the nodes for each year. Each should be interpreted as the standard deviation of the corresponding variable, conditional on the state of the economy in 
year 1 , defined by the initial values of TFP, the labor force, and the capital stock. Because the capital stock is chosen to start the economy on its (stochastic) turnpike path, the subsequent values of the variables are distributed symmetrically around the path as time passes. Some of the variables grow and some have stable distributions around constant means. The upper left graph shows the distribution of TFP, $A$, which is close to a random walk. Its mean grows smoothly and its standard deviation fans out, rising approximately as the square root of the year number. The size of the labor force, $L$, shown in the upper right, behaves similarly, but its growth rate is somewhat higher and its conditional standard deviation is smaller. The variables in the lower part of Figure 17 are not defined in period 1, but, again, the figures show the distributions conditional on the state of the economy in period 1 . The conditional standard deviation of consumption, shown in the lower left, evolves by the same square-root principle as the ones for TFP and the labor force. The unemployment rate, shown in the lower right, has a stationary distribution along the turnpike path.

Table 8 compares the volatility of some of the model's variables to the volatility of the corresponding data. In the case of variables that share the random-walk character of TFP and the labor force, the table describes rates of growth. The left column shows the standard deviations of the variables in the original annual data. The middle column shows the standard deviation, calculated using the model's ergodic distribution, of the state-contingent averages calculated from the original annual data. The right column shows the standard deviations in year 5 of the equilibrium. Comparison of the middle to the left column shows the success of the state setup in capturing the volatility of the corresponding variable. By necessity, the state setup falls short of full success. In most cases, the standard deviation across the states, weighted by the ergodic distribution, is around half of the actual standard deviation. Employment, unemployment, output, consumption, and investment do better than half, while labor-force growth, and the return to capital fall short. Comparison of the right column to the middle column of Table 8 shows the success of the model in matching its target, the state-contingent values in the middle. For TFP growth, labor-force growth, the capital wedge, and the employment wedge, the match is perfect by construction. The match is reasonably good for the other variables. 


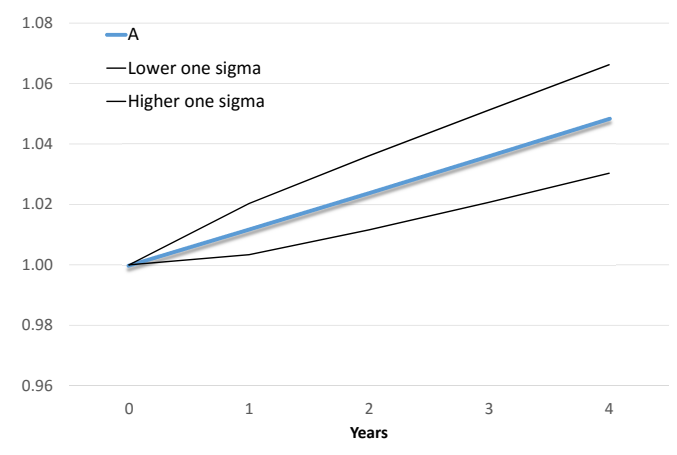

(a) TFP

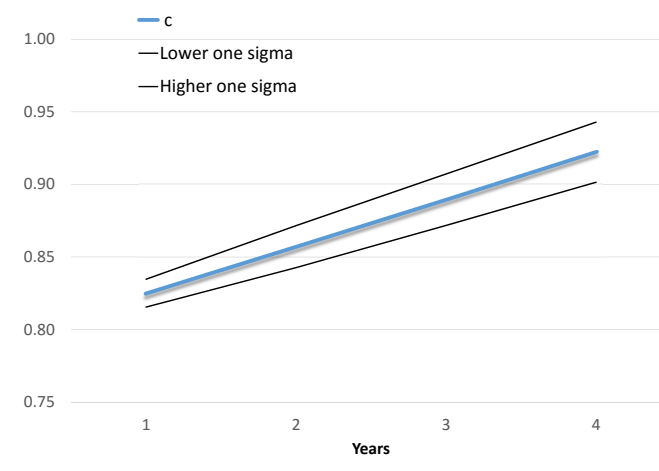

(c) Consumption

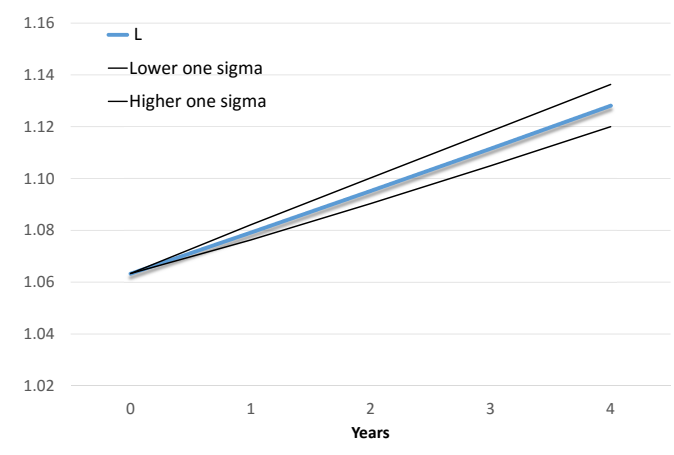

(b) Labor force

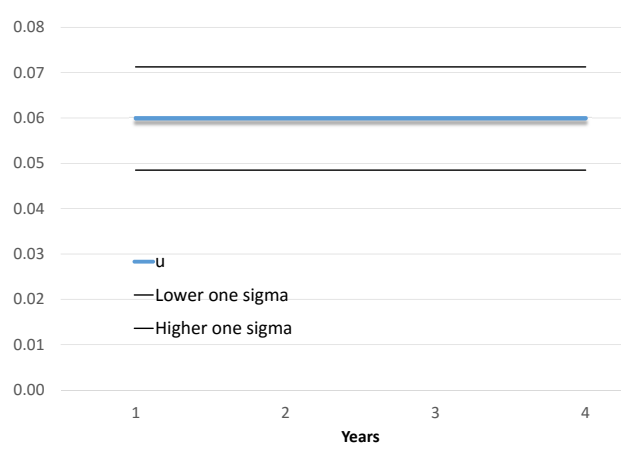

(d) Unemployment rate

Figure 17: Distributions of Four Variables in Equilibrium 


\begin{tabular}{lccc}
\hline \hline & \multicolumn{3}{c}{ Standard deviation } \\
\cline { 2 - 4 } Variable & Data & $\begin{array}{c}\text { State- } \\
\text { based } \\
\text { data }\end{array}$ & Model \\
\hline TFP growth & 1.65 & 0.83 & 0.84 \\
Labor-force growth & 0.81 & 0.27 & 0.27 \\
Capital wedge & $\mathrm{NA}$ & 1.42 & 1.42 \\
Employment wedge & 1.02 & 0.73 & 0.73 \\
Output growth & 2.19 & 1.34 & 1.18 \\
Consumption growth & 1.81 & 1.04 & 1.17 \\
Investment growth & 8.88 & 5.32 & 4.63 \\
Return to capital & 3.81 & 1.05 & 1.63 \\
Unemployment & 1.59 & 1.13 & 1.14 \\
\hline \hline
\end{tabular}

Table 8: Standard Deviations of Selected Variables in the Data and in the Model's Equilibrium

\subsection{Effects of the driving forces}

The popular vector-autoregression framework emphasizes shocks as the starting point for dynamic macro models. Shocks are uncorrelated with each other contemporaneously and uncorrelated with all lagged variables. See Valerie Ramey's chapter in this handbook for a discussion of these assumptions. The framework of this chapter is different. Each year, a new value of the underlying state, $s$, occurs. Its probability distribution is known from the transition probabilities of the Markov process, but the realization from that distribution is a shock. The realization determines the new values of the driving forces. These movements are mutually correlated. Because the model incorporates the hypothesis of rational expectations, adjusted by the known state-dependent distortions, the model incorporates the notion that rational actors respond to the surprise elements of current realizations.

In this framework, it is interesting but challenging to answer questions about the separate effects of the driving forces. Because those forces are correlated, the variance decomposition often presented along with a VAR model is not available - potentially large components of the variance of a given endogenous variable arise from the covariance of a pair of driving forces, so their distinct contributions are not defined. The position of the VAR modeler, as Ramey explains, is that shocks must be uncorrelated, because otherwise they would not have 


\begin{tabular}{lccccc}
\hline \hline & $\begin{array}{c}\text { All driving } \\
\text { forces }\end{array}$ & $\begin{array}{c}\text { TFP } \\
\text { growth } \\
\text { only }\end{array}$ & $\begin{array}{c}\text { Labor- } \\
\text { force } \\
\text { growth } \\
\text { only }\end{array}$ & $\begin{array}{c}\text { Capital } \\
\text { wedge } \\
\text { only }\end{array}$ & $\begin{array}{c}\text { Labor } \\
\text { wedge } \\
\text { only }\end{array}$ \\
\hline Output growth & 1.18 & 0.84 & 0.15 & 0.09 & 0.73 \\
Consumption growth & 1.17 & 0.80 & 0.12 & 0.44 & 0.41 \\
Investment growth & 4.63 & 1.18 & 0.71 & 2.64 & 3.26 \\
Return to capital & 1.63 & 0.62 & 0.26 & 0.84 & 1.03 \\
Unemployment & 1.14 & 0.00 & 0.00 & 0.00 & 1.14 \\
\hline \hline
\end{tabular}

Table 9: Standard Deviations of Selected Variables in Counterfactual Economies with Single Driving Forces

\begin{tabular}{lcccc}
\hline \hline & $\begin{array}{c}\text { TFP } \\
\text { growth }\end{array}$ & $\begin{array}{c}\text { Labor-force } \\
\text { growth }\end{array}$ & $\begin{array}{c}\text { Capital } \\
\text { wedge }\end{array}$ & $\begin{array}{c}\text { Labor } \\
\text { wedge }\end{array}$ \\
\hline TFP growth & 1.00 & & & \\
Labor-force growth & 0.15 & 1.00 & & \\
Capital wedge & 0.83 & -0.03 & 1.00 & \\
Labor wedge & -0.28 & -0.89 & -0.18 & 1.00 \\
\hline \hline
\end{tabular}

Table 10: Correlations of Driving Forces

distinct contributions. The approach in this chapter is that driving forces are fundamental and that their correlation is a matter of measurement, not assumption.

One way to understand the roles of the driving forces is to consider a set of counterfactual economies, each with only one driving force. Table 9 shows the results of that exercise. The top row shows the standard deviations of annual output growth for the base case, with all four driving forces in action, and for the four counterfactuals, with single driving forces. Table 10 shows the correlation matrix of the driving forces, based on the state-contingent values, using the ergodic probabilities (the one-period-ahead correlation matrix is state-dependent). Two correlations stand in the way of even an approximate allocation of explanatory role: The capital wedge is correlated 0.83 with TFP growth and the labor wedge is correlated -0.89 with the labor-force growth.

Table 9 suggests that all four driving forces have important roles in economic fluctuations. An economy with only TFP fluctuations has substantial fluctuations in all of the variables except unemployment. An economy with only labor-force fluctuations has moderate volatility of investment growth-but recall that this driving force is not well captured by the states 
of the model, so this finding probably understates the importance of labor-force fluctuations. An economy with only a capital wedge has some volatility of consumption, quite a bit of volatility of the return to capital, and a lot of volatility of investment. An economy with only a labor wedge has substantial volatility of all the variables.

In addition to the ambiguities associated with the correlation among the four observed driving forces, the results in Table 9 need to be interpreted in the light of the inability to measure other driving forces, notably fluctuations in product demand. The large role of the labor wedge in the table may actually reflect effects operating through shifts of consumption and investment from forces not included in the model. A later section of this chapter on the forces unleashed by the 2008 crisis shows the potential importance of the product-demand and product-market-wedge driving forces.

The model takes a simplified view of the role of confidence, ambiguity aversion, and other factors that may discourage economic activity in ways not included in traditional macro models. Both the capital wedge and the labor wedge are modeled as extra discounts that have adverse effects, but the labor wedge appears to be much the more important of the two. In the model, a decline in confidence and corresponding increase in the labor discount $d_{n}$ has a direct effect on job creation through the mechanisms associated with the DMP model. Lower job creation results in lower job-finding rates and higher unemployment. The result enters the rest of the economy as an adverse shift in net labor supply resulting in declines in output, shared between consumption and investment. As Table 9 shows, in the base model, there is no effect on unemployment from other driving forces - the rise in unemployment in bad times is entirely assigned to a decline in confidence among businesses that cuts back their job-creation flows. Obviously this property is an over-simplification, but the macro-labor research community has made more progress recently in demonstrating the near-irrelevance of driving forces of unemployment such as productivity than in finding driving forces to account for fluctuations in unemployment as responses to other forces. The later section on the crisis shows how the product-market wedge influences unemployment.

\section{Crisis and Slump}

This section explores the model's properties when the driving forces are tuned to data from the years 2009 through 2012, the years of the maximum effects of the crisis of late 2008 and its aftermath. This exercise assigns those four years to an altered state 5 with more 


\begin{tabular}{lc}
\hline \hline Driving force & Value in state 5 \\
\hline TFP growth & 0.92 \\
Labor-force growth & 0.10 \\
Capital discount & 16.70 \\
Liquidity discount & -6.00 \\
Labor discount & 1.96 \\
Product-market wedge & 3.00 \\
Product demand & -5.00 \\
\hline \hline
\end{tabular}

Table 11: Values of Driving Forces Hypothesized for Crisis Slump

negative effects, including values of the two driving forces not measured for the base model covering all the years starting in 1953. Table 11 shows the values for the six driving forces. TFP growth retains its value from the base case, which was close to actual growth over the four years. Labor-force growth is much lower than normal, just above zero. The capital discount is well above its actual value in any state in the base case, reflecting the belief that agency frictions and a loss of confidence occurred during the immediate post-crisis years. The liquidity discount for the safe one-year interest rate is lower than in any state in the base case, reflecting an unusual flight to safety after the crisis. The labor discount is 0.4 percentage points higher than in state 5 in the base case, corresponding to an unemployment rate (with no product-market wedge) around 9 percent, that actually occurred after the crisis. The product-market wedge is taken at the hypothetical value of 3 percent and the product demand shift at minus 5 percent.

Table 12 shows the average effects of the driving forces over the four years of adverse shocks, in comparison to an economy that stayed all four years in a different version of state 5 in which the driving forces all had the average of their values from the base case. Thus the figures in the table are the effects of the crisis in the sense of the differences in the outcomes between an economy with the special crisis driving forces and one with driving forces typical of the US economy historically in normal times. The left column shows the average with all the crisis-specific driving forces in action. The rise of 4.54 percentage points of unemployment resembles the actual behavior of the economy. The decline in output is substantial but falls short of the actual decline of about 10 percent. But the positive numbers for consumption and investment are dramatically the opposite of the actual sharp decline in consumption and collapse of investment. This result is not a failure of the model, but rather a consequence of the model's implication of a huge decline in the safe interest rate. This 
decline could not have occurred, because of the zero lower bound. The story of the table is that the decline in the interest rate unhindered by the lower bound would have brought about an increase in interest-sensitive consumption and investment that would more than offset the direct decline in the spending shift $g$ and the adverse effects of other driving forces.

The right panel of Table 12 breaks down the effects by the driving forces. Because the model is nonlinear, the sum of the effects on the right side is slightly different from the combined effect on the left. The increase in the capital discount had no effect on unemployment, moved a small amount of spending from investment to consumption, lowered output modestly, and depressed the safe interest rate. The rise in the labor discount raised unemployment substantially, and cut output by 1.84 percent, 1.33 percent of output from consumption and 0.51 percent from investment. The rise in the liquidity-safety premium for the short rate had an effect only on that rate, as there is no direct feedback from changes in that rate induced by changes in the premium in the model. The adverse effect of the crisis on the labor force cut output by 1.30 percent. Consumption fell by 1.72 percent of normal output while investment rose by 0.43 percent. The rise in the product-market wedge accounted for 1.61 percentage points of the rise in unemployment, by raising market power and lowering the marginal revenue product of labor and thus cutting the incentive to create jobs. The spending shift, modeled as a decline in government purchases, resulted in increases of 2.51 percent of output in consumption and 1.77 percent in investment, thanks to the income effect of lower implied taxes and the induced decline in the safe short rate of 3.20 percentage points.

\subsection{The zero lower bound}

Obviously the main lesson of Table 12 is the central importance of the zero lower bound for the severity of the post-crisis slump in the U.S. economy. Although the model does not implement a lower bound on the safe real rate, the results are informative about the incidence of the bound and, to some extent, about the magnitude of adverse effects that would have resulted from the bound. During the slump following the 2008 crisis, the short safe nominal rate was essentially zero, at its bound as perceived by the Federal Reserve, and the expected inflation rate was around two percent - see Figure 15 so the corresponding bound on the real rate is around minus two percent. 


\begin{tabular}{lc|cccccc}
\hline \hline \multicolumn{1}{c}{} & \multicolumn{7}{c}{ Driving force } \\
\cline { 2 - 8 } Variable & All & $\begin{array}{c}\text { Capital } \\
\text { discount }\end{array}$ & $\begin{array}{c}\text { Labor } \\
\text { discount }\end{array}$ & $\begin{array}{c}\text { Safe rate } \\
\text { discount }\end{array}$ & $\begin{array}{c}\text { Labor } \\
\text { force }\end{array}$ & $\begin{array}{c}\text { Product } \\
\text { market } \\
\text { wedge }\end{array}$ & $\begin{array}{c}\text { Spending } \\
\text { shift }\end{array}$ \\
\hline $\begin{array}{l}\text { Unemployment, } \\
\text { percentage points }\end{array}$ & 4.54 & 0.00 & 2.98 & 0.00 & 0.00 & 1.61 & 0.00 \\
$\begin{array}{l}\text { Consumption, percent } \\
\text { Output, percent }\end{array}$ & 0.23 & 0.32 & -1.33 & 0.00 & -1.72 & -0.71 & 2.51 \\
$\begin{array}{l}\text { Investment, percent } \\
\begin{array}{l}\text { Safe interest rate, } \\
\text { percentage points }\end{array}\end{array}$ & -3.30 & -0.26 & -1.84 & 0.00 & -1.30 & -1.00 & 0.53 \\
\hline \hline
\end{tabular}

Table 12: Effects of Crisis Shocks on Key Variables, Averaged over Four Years

In the model, the normal value of the safe real rate during the years after 2008 is about three percent. According to the lower left figure in Table 12 , with all driving forces active at the levels in Table 11 , the rate would have been about 11 percent lower, or minus 8 percent. Most macroeconomists would probably agree that the effects of a monetary force that raised the safe real rate 8 percentage points above its equilibrium would be severely contractionary. More than half of that is the direct result of the depression of the safe rate on account of the flight to safety hypothesized in the crisis-slump scenario. The other big negative force is the downward shift in product demand, shown in the lower right corner of Table 12. The model supports the idea that the collapse of house prices and tightening of bank lending battered the economy by discouraging consumption and investment. The third-biggest contributor to the decline in the safe rate was the capital discount, good for about 1.5 percentage points of decline. The labor discount, on the other hand, had only a small effect - it is a supply effect. Whereas demand effects are more than fully offset by the decline in the safe rate, reductions in supply cannot be offset that way.

\section{Persistence}

Effects lasting longer than the driving forces themselves operate through the model's state variables. It has two exogenous state variables, TFP and the labor force, and one endogenous state variable, the capital stock. 


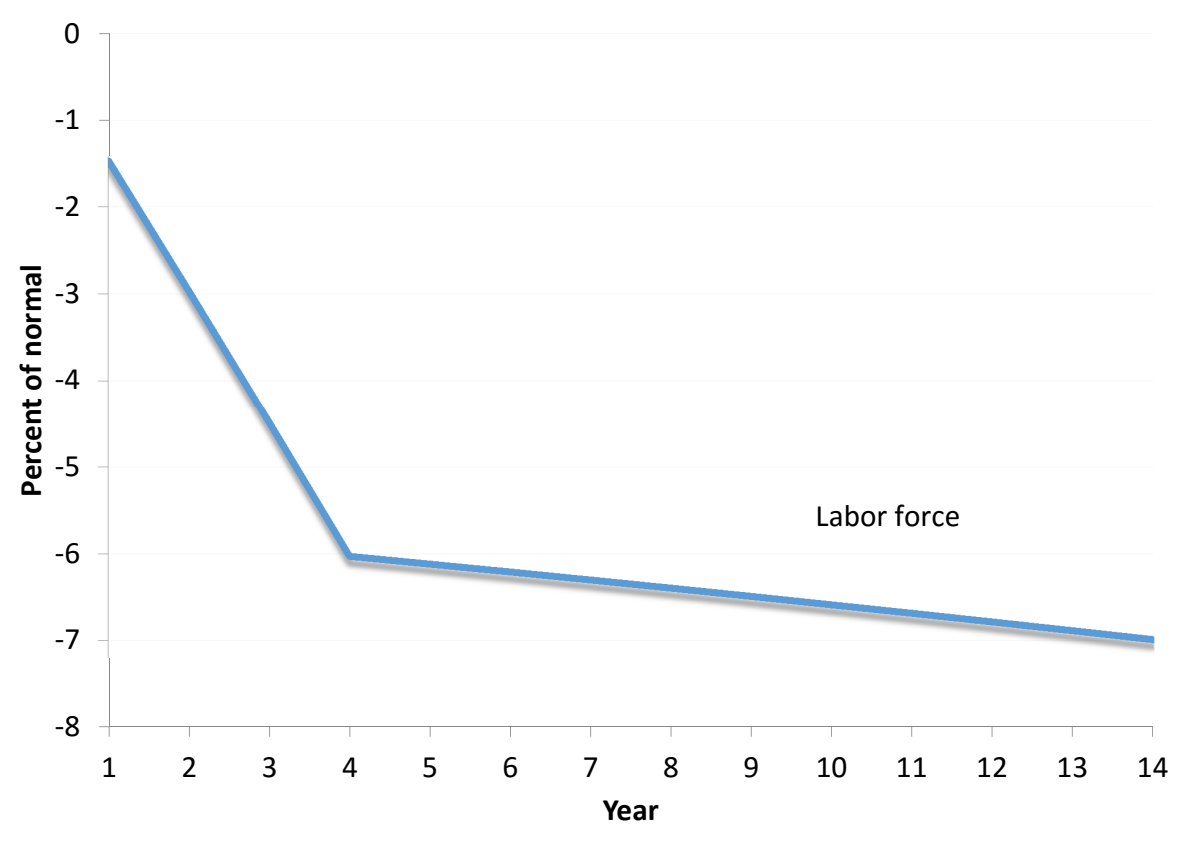

Figure 18: Persistence of a Labor-Force Shock

\subsection{Exogenous Persistence}

In the model, each shock to the labor force has permanent effects. Where the shocks operate through births and immigration, this property is a reasonable approximation. Whether the substantial decline in the labor-force participation of existing individuals that occurred during the slump will ultimately reverse itself is an open question. As of early 2016, there was no sign that the return to essentially normal conditions in the labor market would result in a restoration of any of the large decline that accompanied the slump. Figure 18 shows the path of the labor force as a percent of its initial normal value in the hypothetical crisis slump studied in the previous section. With 4 consecutive large incremental shortfalls in the labor force during years one to four, the cumulative shortfall in the labor force in year four is about six percent. Though the labor-force growth rate returns to normal in year five, the cumulative shortfall continues to become larger, because the growth process is multiplicative and is always at a lower base, post-crisis.

\subsection{Endogenous Persistence}

Endogenous persistence occurs through the capital stock. The effect of the capital discount is concentrated on investment, as shown in Table 12. An increase in that discount causes 


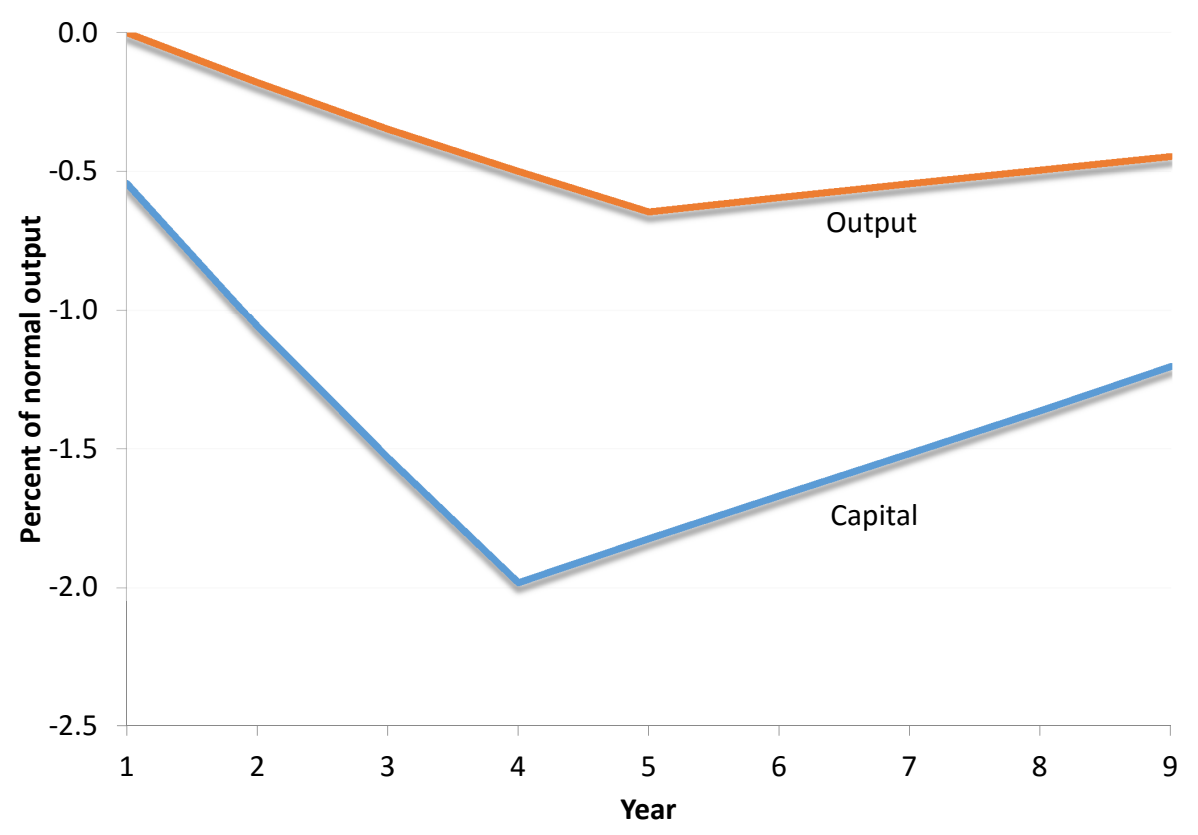

Figure 19: Persistent Effects of an Elevation of the Capital Discount

businesses to place a lower value on the future payoff to capital formation, so capital falls further and further below its normal growth path during a period of higher discount. The effects on output and other variables persist beyond the time when the discount declines back to normal. The capital stock returns only gradually to its normal growth path. Figure 19 shows the effects of the 4-year period of increased capital discount described in Table 11 on the capital stock and on output. The figure shows the difference between the expected values of those variables conditional on the crisis values of the capital discount and the expected values with normal, non-crisis values of the discount. The effects on both variables cumulate during the four years with the higher crisis discount and then begin to return toward zero. Five years after the end of the crisis values, the effects remain strong.

Similar results apply to the other driving forces that have negative effects on investment in Table 11. These are the labor discount, which cuts investment by reducing the effective supply of labor, and the product-market wedge, which lowers the marginal revenue product of capital. 


\section{Concluding Remarks}

This chapter is complementary to Ramey's chapter in this volume. Most of her discussion relates to empirical evidence from VARs and other econometric specifications, or to the properties of New Keynesian structural models, though she does also consider structural models more closely affiliated with the tradition of the real business cycle model. She focuses extensively on monetary shocks - departures of monetary policy from its usual relation to current developments in the economy. No monetary shocks occur in the economy considered in this chapter. The central bank never pushes the short rate away from its equilibrium value to restore inflation to its target rate. In the context of the literature that includes monetary policy and monetary non-neutrality, the model here reveals the values of the interest rate and other variables that would prevail in the absence of sticky prices and wages. Both chapters consider government purchases as a driving force. In the empirical work Ramey considers, the focus is on the purchases multiplier, as revealed by the empirical relation between output and purchases. She finds that the multiplier is around one but with considerable dispersion across studies. In this chapter, Table 12 shows a multiplier of 0.53 , the value in the row for output and the column for the spending shift. The lower value may be the result of the model's assumption of full monetary response to government purchases, letting the interest rate track the change in its equilibrium value. The sample period for the model includes times when, for example, monetary policy kept the interest rate constant in the face of an increase in purchases, which would considerably amplify the response of output. On the tax side of fiscal policy, Ramey considers taxes as explicit driving forces. Taxes have a role in this chapter because they are one of the sources of historical shifts in the capital discount. But I do not consider tax changes as special driving forces of the post-crisis slump. Ramey's chapter includes a detailed treatment of the measurement of technology shifts and their effects, as measured in empirical work. To measure TFP growth, she concludes in favor of measures with utilization adjustments. This chapter uses Fernald's measure without that adjustment. She also discusses, in detail, measures of technological change apart from TFP, relating to investment. She briefly mentions oil-price changes, credit conditions, policy uncertainty, fluctuations in the labor force, and the labor wedge as additional driving forces. She does not mention the product-market wedge as a driving force.

The importance of total factor productivity as a determinant of medium-term growth and economic performance is widely agreed among macroeconomists today, and is confirmed in 
the results of this chapter - Table 9 shows that, historically, movements of TFP by themselves would account for a standard deviation of output around 75 percent of the total of all driving forces. A decline in productivity growth occurred during the slump that began in 2008 and contributed to the shortfall in output, consumption, and capital formation during the slump. Whether the crisis of 2008 contributed to the decline in productivity growth is unresolved.

On the other hand, fluctuations in the size of the work force relative to the working-age population - the labor-force participation rate - are about as big as fluctuations in productivity and have similar effects. Research on medium-run fluctuations has neglected this driving force, even though research on participation itself has been extensive. The continuation during the recent slump of a major decline in participation that began in 2000 - and is not the result of demographic shifts - worsened the slump. The evidence seems to point in the direction that the decline in participation was not the result of the crisis and resulting explosion of unemployment.

Evidence from financial markets appears to confirm the proposition that discounts applied to risky investments rose as a result of the crisis even as the safe rate fell to zero. In normal times, without the zero lower bound, higher discounts result in lower output and employment. There is an interesting unresolved question about the role of discount increases when the real rate is held fixed by the zero lower bound on the nominal interest rate and the immovability of inflation.

Models that attribute some of the depth and persistence of the response of the economy to financial shocks hold that the shocks cause increases in agency frictions within financial intermediaries or non-financial businesses. Financial wedges develop to ensure that managers deprived of equity still have continuation values sufficient to prevent misconduct. The evidence of widening wedges between the return to capital and the safe short rate is convincing, as is the sharp but transitory rise in the spreads between risky private bonds and Treasurys of the same maturity. The model in this chapter assigns a moderate but important role to financial frictions, as part of the driving force called the capital discount.

The New Keynesian model has called attention to the product-market wedge - the markup of price over cost — as the transmission mechanism of shocks to economic activity. With sticky prices, an increase in demand raises cost but not price, so the markup declines. The economy expands because the product-market wedge functions like a tax wedge in depressing activity and the decline in markups relieves that adverse effect. An interesting debate has 
yet to resolve the issue of the importance of the product-market wedge in the depth and persistence of slumps.

Finally, the model confirms earlier findings about the multiplier effects of shifts in product demand. As an important cause of declining consumption demand, household deleveraging has been assigned a major role in the recent slump and is an obvious candidate for explaining the persistence of the slump. In the model, an exogenous decline in product demand results in a large decrease in the interest rate, which stimulates consumption and investment. Rather than collapsing, the economy undergoes a large reallocation of resources. But with the zero lower bound in effect, the reallocation fails to occur. Instead, output and employment fall. As yet, the profession has not come forth with a well-founded model of that failure. 


\section{References}

Adrian, Tobias, Paolo Colla, and Hyun Song Shin, "Which Financial Frictions? Parsing the Evidence from the Financial Crisis of 2007-9," Working Paper 18335, National Bureau of Economic Research, August 2012.

Aguiar, Mark, Erik Hurst, and Loukas Karabarbounis, "Time Use during the Great Recession," American Economic Review, 2013, 103, 1664-96.

Angeletos, George-Marios, Fabrice Collard, and Harris Dellas, "Quantifying Confidence," Working Paper 20807, National Bureau of Economic Research, December 2014.

Attanasio, Orazio P. and Guglielmo Weber, "Is Consumption Growth Consistent with Intertemporal Optimization? Evidence from the Consumer Expenditure Survey," Journal of Political Economy, 1995, 103 (6), 1121-1157.

Autor, David H., "The Unsustainable Rise of the Disability Rolls in the United States: Causes, Consequences, and Policy Options," Working Paper 17697, National Bureau of Economic Research, December 2011.

Ball, Laurence and Sandeep Mazumder, "The Evolution of Inflation Dynamics and the Great Recession," Brookings Papers on Economic Activity, 2011, (1), 337-405.

Barnichon, Regis and Andrew Figura, "The Determinants of the Cycles and Trends in U.S. Unemployment," June 2012. Federal Reserve Board.

Barro, Robert J. and Charles J. Redlick, "Macroeconomic Effects from Government Purchases and Taxes," Quarterly Journal of Economics, 2011, 126 (1), 51-102.

Benigno, Gianluca and Luca Fornaro, "Stagnation Traps," January 2015. London School of Economics.

Bernanke, Ben S., Mark Gertler, and Simon Gilchrist, "The Financial Accelerator in a Quantitative Business Cycle Framework," in John B. Taylor and Michael Woodford, eds., Handbook of Macroeconomics, Elsevier, 1999, chapter 21, pp. 1341-1393.

Bhutta, Neil, "Mortgage Debt and Household Deleveraging: Accounting for the Decline in Mortgage Debt Using Consumer Credit Record Data," Technical Report 2012-14, 
Finance and Economics Discussion Series, Divisions of Research \& Statistics and Monetary Affairs, Federal Reserve Board, Washington, D.C. 2012.

Bianchi, Francesco, Cosmin Ilut, and Martin Schneider, "Uncertainty Shocks, Asset Supply and Pricing over the Business Cycle," December 2012. Duke University, Department of Economics.

Bils, Mark, Peter J. Klenow, and Benjamin A. Malin, "Resurrecting the Role of the Product Market Wedge in Recessions," Working Paper 20555, National Bureau of Economic Research, October 2014.

Blundell, Richard, Luigi Pistaferri, and Ian Preston, "Consumption Inequality and Partial Insurance," American Economic Review, December 2008, 98 (5), 1887-1921.

Brunnermeier, Markus K. and Yuliy Sannikov, "A Macroeconomic Model with a Financial Sector," American Economic Review, 2014, 104 (2), 379-421.

, Thomas M. Eisenbach, and Yuliy Sannikov, "Macroeconomics with Financial Frictions: A Survey," Working Paper 18102, National Bureau of Economic Research, May 2012 .

Campbell, John Y. and Robert J. Shiller, "The Dividend-Price Ratio and Expectations of Future Dividends and Discount Factors," Review of Financial Studies, 1988, 1 (3), $195-228$.

Chari, V. V., Patrick J. Kehoe, and Ellen R. McGrattan, "Business Cycle Accounting," Econometrica, May 2007, 75 (3), 781-836.

Chodorow-Reich, Gabriel, "The Employment Effects of Credit Market Disruptions: Firmlevel Evidence from the 2008-9 Financial Crisis," Quarterly Journal of Economics, 2014, $129(1), 1-59$.

and Loukas Karabarbounis, "The Cyclicality of the Opportunity Cost of Employment," Journal of Political Economy, 2016. Forthcoming.

Christiano, Lawrence J., Martin Eichenbaum, and Sergio Rebelo, "When Is the Government Spending Multiplier Large?," Journal of Political Economy, February 2011, 119 (1), 78121. 
, Martin S. Eichenbaum, and Mathias Trabandt, "Unemployment and Business Cycles," Econometrica, 2016. Forthcoming.

, Mathias Trabandt, and Karl Walentin, "DSGE Models for Monetary Policy Analysis," Working Paper 16074, National Bureau of Economic Research, June 2010.

Cochrane, John H., "Presidential Address: Discount Rates," Journal of Finance, 2011, 66 (4), $1047-1108$.

__ "The New-Keynesian Liquidity Trap," June 2014. Booth School of Business, University of Chicago.

Coenen, Gnter, Christopher J. Erceg, Charles Freedman, Davide Furceri, Michael Kumhof, Ren Lalonde, Douglas Laxton, Jesper Lind, Annabelle Mourougane, Dirk Muir, Susanna Mursula, Carlos de Resende, John Roberts, Werner Roeger, Stephen Snudden, Mathias Trabandt, and Jan in't Veld, "Effects of Fiscal Stimulus in Structural Models," American Economic Journal: Macroeconomics, 2012, 4 (1), 22-68.

Cole, Harold and Richard Rogerson, "Can the Mortensen-Pissarides Matching Model Match the Business Cycle Facts?," International Economic Review, 1999, 40 (4), 933-960.

Comin, Diego and Mark Gertler, "Medium-Term Business Cycles," American Economic Review, 2006, 96 (3), 523-551.

Correia, Isabel, Emmanuel Farhi, Juan Pablo Nicolini, and Pedro Teles, "Policy at the Zero Bound," December 2010. Banco de Portugal.

Cúrdia, Vasco and Michael Woodford, "Credit Frictions and Optimal Monetary Policy," Working Paper 21820, National Bureau of Economic Research, December 2015.

Daly, Mary, Bart Hobijn, Ayşegül Şahin, and Rob Valletta, "A Rising Natural Rate of Unemployment: Transitory or Permanent?," Working Paper 2011-05, Federal Reserve Bank of San Francisco, September 2011.

Daly, Mary C., Bart Hobijn, and Robert G. Valletta, "The Recent Evolution of the Natural Rate of Unemployment," 2011. IZA Discussion Paper No. 5832. 
__ _ _ Ayş̧egül Şahin, and Robert G. Valletta, "A Search and Matching Approach to Labor Markets: Did the Natural Rate of Unemployment Rise," Journal of Economic Perspectives, Summer 2012, 26 (3), 3-26.

Davis, Steven J. and John Haltiwanger, "Labor Market Fluidity and Economic Performance," Procedings of the Jackson Hole Symposium, Federal Reserve Bank of Kansas, September 2014, pp. 17-107.

and Till von Wachter, "Recessions and the Costs of Job Loss," Brookings Papers on Economic Activity, Fall 2011, (2), 1-55.

, R. Jason Faberman, and John C. Haltiwanger, "Recruiting Intensity during and after the Great Recession: National and Industry Evidence," American Economic Review Papers and Proceedings, May 2012, 102 (3), 584-88.

De Nardi, Mariacristina, Eric French, and David Benson, "Consumption and the Great Recession," Working Paper 17688, National Bureau of Economic Research, December 2011.

Dynan, Karen, "Is a Household Debt Overhang Holding Back Consumption?," Brookings Papers on Economic Activity, 2012, pp. 299-362.

Eckstein, Zvi, Ofer Setty, and David Weiss, "Financial Risk and Unemployment," March 2015. Tel Aviv University.

Eggertsson, Gauti B. and Neil R. Mehrotra, "A Model of Secular Stagnation," Working Paper 20574, National Bureau of Economic Research, October 2014.

and Paul Krugman, "Debt, Deleveraging, and the Liquidity Trap: A Fisher-MinskyKoo Approach.," Quarterly Journal of Economics, 2012, 127 (3), 1469 - 1513.

Elsby, Michael W.L., Bart Hobijn, and Ayşegül Şahin, "On the Importance of the Participation Margin for Market Fluctuations," Working Paper 2013-05, Federal Reserve Bank of San Francisco, February 2013.

, and Robert G. Valletta, "The Labor Market in the Great Recession: An Update to September 2011," Brookings Papers on Economic Activity, 2011, pp. 353-384. 
Estevão, Marcello and Evridiki Tsounta, "Has the Great Recession Raised U.S. Structural Unemployment?," May 2011. International Monetary Fund.

Farber, Henry S., "Job Loss in the Great Recession and its Aftermath: U.S. Evidence from the Displaced Workers Survey," Working Paper 21216, National Bureau of Economic Research May 2015.

and Robert G. Valletta, "Do Extended Unemployment Benefits Lengthen Unemployment Spells? Evidence from Recent Cycles in the U.S. Labor Market," Working Paper 19048, National Bureau of Economic Research, May 2013.

Farhi, Emmanuel and Iván Werning, "A Theory of Macroprudential Policies in the Presence of Nominal Rigidities," October 2013. Department of Economics, Harvard University.

Farmer, Roger E.A., "The Stock Market Crash of 2008 Caused the Great Recession: Theory and Evidence," Journal of Economic Dynamics and Control, 2012, 36 (5), 693 - 707.

Fernald, John, "Productivity and Potential Output Before, During, and After the Great Recession," NBER Macroeconomics Annual, 2014.

Fernald, John G., "A Quarterly, Utilization-Adjusted Series on Total Factor Productivity," September 2012. 2012-19, Federal Reserve Bank of San Francisco. Updated regularly on Fernald's FRBSF website.

Fleckenstein, Matthias, Francis A. Longstaff, and Hanno Lustig, "Deflation Risk," July 2013. Anderson School, UCLA.

Friedman, Milton, "Presidential Address," American Econmic Review, March 1968, 58 (1), $1-15$.

Fujita, Shigeru, "Effects of Extended Unemployment Insurance Benefits: Evidence from the Monthly CPS," January 2011. Federal Reserve Bank of Philadelphia. and Giuseppe Moscarini, "Recall and Unemployment," Working Paper 19640, National Bureau of Economic Research, November 2013.

Gertler, Mark and Nobuhiro Kiyotaki, "Financial Intermediation and Credit Policy in Business Cycle Analysis," in Benjamin Friedman and Michael Woodford, eds., Handbook of Monetary Economics, Elsevier, 2011, pp. 547-599. 
and Peter Karadi, "A model of unconventional monetary policy," Journal of Monetary Economics, 2011, 58 (1), 17 - 34. Carnegie-Rochester Conference Series on Public Policy: The Future of Central Banking April 16-17, 2010.

_ _ Luca Sala, and Antonella Trigari, "An Estimated Monetary DSGE Model with Unemployment and Staggered Nominal Wage Bargaining," Journal of Money, Credit and Banking, 2008, 40 (8), 1713-1764.

Gilchrist, Simon, Jae W. Sim, and Egon Zakrajek, "Uncertainty, Financial Frictions, and Investment Dynamics," Working Paper 20038, National Bureau of Economic Research, April 2014.

_ _ Raphael Schoenle, Jae W. Sim, and Egon Zakrašek, "Inflation Dynamics During the Financial Crisis," January 2014. Department of Economics, Boston Uniersity.

Gomme, Paul, B. Ravikumar, and Peter Rupert, "The Return to Capital and the Business Cycle," Review of Economic Dynamics, 2011, 14 (2), 262-278.

Gourio, François, "Disaster Risk and Business Cycles," American Economic Review, September 2012, 102 (6), 2734-66.

and Leena Rudanko, "Customer Capital," Review of Economic Studies, 2014, 81 (3), $1102-1136$.

Hagedorn, Marcus, Fatih Karahan, Iourii Manovskii, and Kurt Mitman, "Unemployment Benefits and Unemployment in the Great Recession: The Role of Macro Effects," Working Paper 19499, National Bureau of Economic Research, October 2013.

Hall, Robert E., "Lost Jobs," Brookings Papers on Economic Activity, 1995, (1), 221-273.

__ "Measuring Factor Adjustment Costs," Quarterly Journal of Economics, August 2004, $119(3), 899-927$.

_ _ "Separating the Business Cycle from Other Economic Flucutations," The Greenspan Era: Lessons for the Future, Proceedings of the Federal Reserve Bank of Kansas City, August 2005, pp. 133-179.

_ _ "By How Much Does GDP Rise If the Government Buys More Output?," Brookings Papers on Economic Activity, 2009, (2), 183-231. 
_ _ "The High Sensitivity of Economic Activity to Financial Frictions," Economic Journal, May 2011, 121, 351-378.

__ "The Long Slump," American Economic Review, April 2011, 101 (2), 431-69. 2011 AEA Presidential Address.

_ _ "How the Financial Crisis Caused Persistent Unemployment," in Ian J. Wright Lee E. Ohanian, John B. Taylor, ed., Government Policies and the Delayed Economic Recovery, Hoover Institution Press, 2012, pp. 57-83.

_ _ "The Routes into and out of the Zero Lower Bound," Proceedings of the Jackson Hole Symposium, Federal Reserve Bank of Kansas City, 2013, pp. 1-35.

_ , "Quantifying the Lasting Harm to the U.S. Economy from the Financial Crisis," NBER Macroeconomics Annual, 2014, pp. 71-128.

_ _ "High Discounts and High Unemployment," October 2015. Hoover Institution, Stanford University.

_ , "Search-and-Matching Analysis of High Unemployment Caused by the Zero Lower Bound," Review of Economic Dynamics, 2016. Forthcoming.

— and Sam Schulhofer-Wohl, "Measuring Job-Finding Rates and Matching Efficiency with Heterogeneous Jobseekers," Working Paper 20939, National Bureau of Economic Research, February 2015.

He, Zhiguo and Arvind Krishnamurthy, "Intermediary Asset Pricing," American Economic Review, 2013, 103 (2), 732-70. and __ , "A Macroeconomic Framework for Quantifying Systemic Risk," March 2015. Graduate school of Business, Stanford University.

Herz, Benedikt and Thijs van Rens, "Structural Unemployment," July 2011. Universitat Pompeu Fabra.

Hyatt, Henry R. and James R. Spletzer, "The Recent Decline in Employment Dynamics," March 2013. Center for Economic Studies, US Census Bureau. 
Jarosch, Gregor, "Searching for Job Security and the Consequences of Job Loss," November 2014. Department of Econmics, University of Chicago.

Kaplan, Greg and Giovanni L. Violante, "A Model of the Consumption Response to Fiscal Stimulus Payments," Econometrica, 2014, 82 (4), 1199-1239.

and Guido Menzio, "Shopping Externalities and Self-Fulfilling Unemployment Fluctuations," Journal of Political Economy, 2016. Forthcoming.

Karabarbounis, Loukas and Brent Neiman, "The Global Decline of the Labor Share," The Quarterly Journal of Economics, 2014, 129 (1), 61-103.

Kiyotaki, Nobuhiro and John Moore, "Liquidity, Business Cycles, and Monetary Policy," Working Paper 17934, National Bureau of Economic Research, March 2012.

Kocherlakota, Narayana R., "Impact of a Land Price Fall When Labor Markets are Incomplete," April 2013. Federal Reserve Bank of Minneapolis.

Korinek, Anton and Alp Simsek, "Liquidity Trap and Excessive Leverage," Working Paper 19970, National Bureau of Economic Research, March 2014.

Kozlowski, Julian, Laura Veldkamp, and Venky Venkateswaran, "The Tail that Wags the Economy: Belief-Driven Business Cycles and Persistent Stagnation," Working Paper 21719, National Bureau of Economic Research November 2015.

Krishnamurthy, Arvind and Annette Vissing-Jorgensen, "Short-term Debt and Financial Crises: What We Can Learn from U.S. Treasury Supply," May 2013. Kellogg School, Northwestern University.

Krueger, Alan B. and Andreas I. Mueller, "Job Search, Emotional Well-Being, and Job Finding in a Period of Mass Unemployment: Evidence from High-Frequency Longitudinal Data," Brookings Papers on Economic Activity, Spring 2011, (1), 1-70.

— the Labor Market?," Brookings Papers on Economic Activity, Spring 2014.

Krugman, Paul R., "It's Baaack: Japan's Slump and the Return of the Liquidity Trap," Brookings Papers on Economic Activity, 1998, (2), 137-205. 
Kuehn, Lars-Alexander, Nicolas Petrosky-Nadeau, and Lu Zhang, "An Equilibrium Asset Pricing Model with Labor Market Search," January 2013. Carnegie Mellon University, Tepper School of Business.

Ludvigson, Sydney C., Sai Ma, and Serena Ng, "Uncertainty and Business Cycles: Exogenous Impulse or Endogenous Response?," Working Paper 21803, National Bureau of Economic Research, December 2015.

Lustig, Hanno and Adrien Verdelhan, "Business Cycle Variation in the Risk-Return Tradeoff," Journal of Monetary Economics, October 2012, 59, S35-S49.

_ _ Stijn Van Nieuwerburgh, and Adrien Verdelhan, "The Wealth-Consumption Ratio," Review of Asset Pricing Studies, 2013, 3 (1), 38-94.

Mian, Atif and Amir Sufi, "The Great Recession: Lessons from Microeconomic Data," American Economic Review, 2010, 100 (2), pp. 51-56.

— Kamalesh Rao, and Amir Sufi, "Household Balance Sheets, Consumption, and the Economic Slump," Quarterly Journal of Economics, 2013, 128 (4), 1687-1726.

Mian, Atif R. and Amir Sufi, "What Explains High Unemployment? The Aggregate Demand Channel," Working Paper 17830, National Bureau of Economic Research, February 2012.

Michaillat, Pascal and Emmanuel Saez, "An Economical Business-Cycle Model," Working Paper 19777, National Bureau of Economic Research, January 2014.

Mortensen, Dale T., "Comments on Hall's Clashing Theories of Unemployment," July 2011. Department of Economics, Northwestern University.

Mulligan, Casey B., "Do Welfare Policies Matter for Labor Market Aggregates? Quantifying Safety Net Work Incentives since 2007," Working Paper 18088, National Bureau of Economic Research, May 2012.

— The Redistribution Recession: How Labor Market Distortions Contracted the Economy, New York: Oxford University Press, 2012.

Nekarda, Christopher J. and Valerie A. Ramey, "The Cyclical Behavior of the Price-Cost Markup," Working Paper 19099, National Bureau of Economic Research, June 2013. 
Parker, Jonathan A., Nicholas S. Souleles, David S. Johnson, and Robert McClelland, "Consumer Spending and the Economic Stimulus Payments of 2008," Working Paper 16684, National Bureau of Economic Research, January 2011.

Petev, Ivaylo, Luigi Pistaferri, and Itay Saporta Eksten, "Consumption and the Great Recession: An Analysis of Trends, Perceptions, and Distributional Effects," in David B. Grusky, Bruce Western, and Christopher Wimer, eds., The Great Recession, Russell Sage Foundation, 2012.

Petrosky-Nadeau, Nicolas and Etienne Wasmer, "The Cyclical Volatility of Labor Markets under Frictional Financial Markets," American Economic Journal: Macroeconomics, 2013, 5 (1), 193-221.

and __ , "Macroeconomic Dynamics in a Model of Goods, Labor, and Credit Market Frictions," Journal of Monetary Economics, forthcoming, 2015.

and Lu Zhang, "Unemployment Crises," Working Paper 19207, National Bureau of Economic Research, July 2013.

Phelps, Edmund S. and Sidney G. Winter, "Optimal Price Policy under Atomistic Competition," in Edmund S. Phelps, ed., Microeconomic Foundations of Employment and Inflation Theory, New York: W.W. Norton, 1970, pp. 309-337.

Philippon, Thomas, "The Bond Market's q," Quarterly Journal of Economics, August 2009, $124(3), 1011-1056$.

Ramey, Valerie A., "Can Government Purchases Stimulate the Economy?," Journal of Economic Literature, 2011, 49 (3), 673-85.

__ , "Identifying Government Spending Shocks: It's all in the Timing," Quarterly Journal of Economics, 2011.

Ravn, Morten O. and Vincent Sterk, "Job Uncertainty and Deep Recessions," December 2012. University College London.

Reifschneider, Dave, William Wascher, and David Wilcox, "Aggregate Supply in the United States: Recent Developments and Implications for the Conduct of Monetary Policy," Technical Report, Finance and Economics Discussion Series Divisions of Research \& 
Statistics and Monetary Affairs Federal Reserve Board, Washington, D.C., November 2013.

Restrepo, Pascual, "Skill Mismatch and Structural Unemployment," November 2015. Massachusetts Institute of Technology.

Rognlie, Matthew, "Deciphering the Fall and Rise in the Net Capital Share," Broookings Papers on Economic Acdtivity, 2015, (2). Forthcoming.

Rotemberg, Julio J. and Michael Woodford, "The Cyclical Behavior of Prices and Costs," 1999. in Taylor and Woodford, eds., Handbook of Macroeconomics, Chapter 16, pp. 1051-1135, 1999.

Rothstein, Jesse, "Unemployment Insurance and Job Search in the Great Recession," Brookings Papers on Economic Activity, Fall 2011, pp. 143-2010.

Sahin, Ayşegül, Joseph Song, Giorgio Topa, and Giovanni L. Violante, "Mismatch Unemployment," Working Paper 18265, National Bureau of Economic Research, August 2012.

Shapiro, Matthew D. and Joel Slemrod, "Did the 2008 Tax Rebates Stimulate Spending?," American Econmic Review Papers and Proceedings, May 2009, 99 (2), 374-379.

Shimer, Robert, "The Cyclical Behavior of Equilibrium Unemployment and Vacancies," American Economic Review, 2005, 95 (1), 24-49.

_ _ "Convergence in Macroeconomics: The Labor Wedge," American Economic Journal: Macroeconomics, 2008, 1 (1), 280-297.

Spilimbergo, Antonio, Steve Symansky, and Martin Schindler, "Fiscal Multipliers," May, IMF Staff Position Note 2009.

Stock, James H. and Mark W. Watson, "Modeling Inflation after the Crisis," Proceedings of the Economic Policy Symposium, 2010, pp. 172-220. Federal Reserve Bank of Kansas City.

Valletta, Rob and Katherine Kuang, "Extended Unemployment and UI Benefits," Federal Reserve Bank of San Francisco Economic Letter, April 2010, pp. 1-4. 
__ and _ _ "Is Structural Unemployment on the Rise?," Federal Reserve Bank of San Francisco Economic Letter, November 2010, pp. 1-5.

Walsh, Carl E., "Labor Market Search and Monetary Shocks," in S. Altug, J. Chadha, and C. Nolan, eds., Elements of Dynamic Macroeconomic Analysis, Cambridge University Press, 2003, pp. 451-486. 